\title{
Borohydrides as Solid-State Hydrogen Storage Materials: Past, Current Approaches and Future Perspectives
}

\author{
Qiwen Lai and Kondo-Francois Aguey-Zinsou* \\ MERLin, School of Chemical Engineering, The University of New South Wales, Sydney NSW 2052, Australia \\ Email: f.aguey@unsw.edu.au (K. A.)
}

\begin{abstract}
For long, the focus on hydrogen as an energy vector has been towards vehicle applications to decrease air pollution across cities and reduce our reliance on fossil fuels for transport. However, hydrogen has also the potential to enable the transition of current energy schemes towards clean and sustainable energy systems based on renewable energy. The major drawback remains the development of materials/methods for the safe storage of hydrogen with high-energy density. Recently, the idea of using borohydrides for hydrogen storage has gained increasing attention because of the high hydrogen density provided by these materials. However, the high temperatures for hydrogen release from these materials and their slow hydrogen kinetics remain the main challenges. Herein, current approaches to tailor the hydrogen storage properties of borohydrides towards practical applications are reviewed, including the restriction of borohydrides within various nanosized scaffolds. A summary of the remaining challenges and potential future research directions is also provided.
\end{abstract}

Keywords hydrogen storage, borohydride, hydrogen sorption

\section{Introduction}

The energy problem is one of the top 10 issues facing humankind in the current century. The world's primary energy consumption increases on average by $1.8 \%$ per year. This is driven by the surges in productivity (i.e., GDP per person), increasing population and the emerging economies. The world's primary energy source still relies strongly on fossil fuels (32\% oil, $31 \%$ coal and $24 \%$ gas) and the penetration of renewable energy is still very limited (i.e., $3 \%$ ). The consumption of gas and oil are continuing to grow at a rate of $1.6 \%$ and $0.7 \%$ p.a., respectively, while the growth of coal is marginally reduced to $0.2 \%$ p.a. The fear of running out of the long-relied-on energy sources is driving us towards more sustainable energy systems. Significant investments are going into renewables, making this the fastest growing energy source ( $7 \%$ per year). It is projected that the renewable energy share in the energy market will have tripled to $\sim 10 \%$ by $2035^{[1]}$

The environmental concern raised by high-carbon-content fossil fuel consumption is another reason driving the shift to cleaner energy sources. Air pollution and solid waste from manufacturing and combustion of fossil fuels are putting our living environment in danger. Greenhouse gases are rapidly changing the global climate, influencing our air quality and creating a great impact on agriculture and food production. The cost of management of carbon dioxide release might eventually make fossil fuels less attractive compared to other energy sources. ${ }^{[2]}$ It is believed that only hydrogen-based energy carriers and low-carbon technologies can achieve up to $80 \%$ reduction of $\mathrm{CO}_{2}$ emissions. ${ }^{[3]}$ The Paris Agreement on climate change enforced in November 2016 calls for the transformation of two-thirds of the current energy sector to achieve a limitation of global warming to $2^{\circ} \mathrm{C}$ by 2100 . As a result, more investment is needed to develop clean energy technologies including solar and wind farms. ${ }^{[1]}$
The amount of renewable energy available to us is sustainable and unlimited. Using renewables has also a relatively small environmental impact. However, the use of renewable energy is limited by the lack of energy storage technologies. For example, solar energy can only be used while sunlight is available, and the excess of energy produced during the day cannot be utilized at night-time unless it is stored. Furthermore, the availability and supply of renewable energy are generally intermittent. As a consequence, storage remains critical to the uptake of renewable energy. ${ }^{[4]}$

Batteries have been developed over the last century to provide means to store energy in a chemical form. However, as shown in Figure 1, their energy densities are extremely low, compared to the conventional fossil fuels. There are many types of batteries on the market: Lead-acid batteries have been

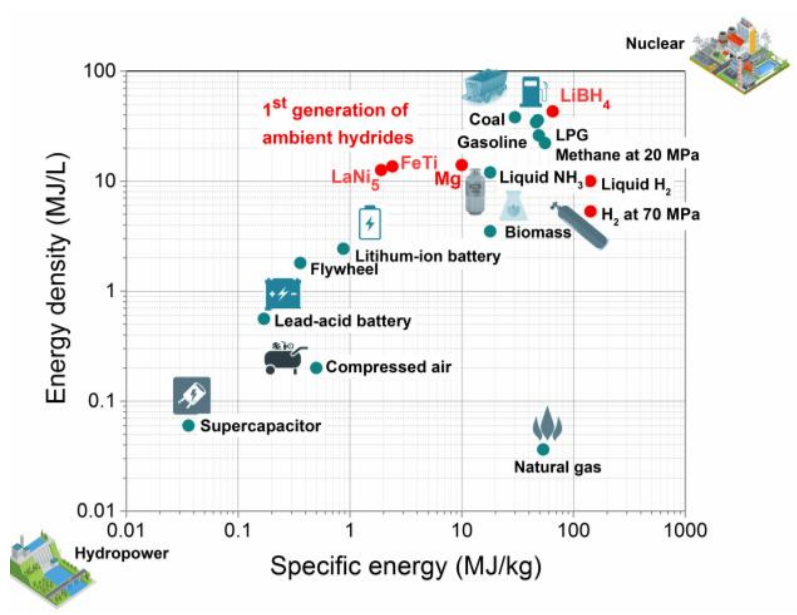

Figure 1 Specific energy and energy density of selected energy storage technologies. 
used in cars to supply electricity on board for the past century. However, these batteries have still a significant limitation on their energy density. Sodium-sulphur batteries have a higher energy density but a high operation temperature (i.e., $300^{\circ} \mathrm{C}$ ). The sodium and sulphur need to be separated in their molten state and complete discharge of the battery is not allowed to avoid irreparable damages. ${ }^{[4]}$ Lithium-ion batteries have a relatively higher energy density and efficiency. The only problem is their cost, which makes them the favoured solution for application in small high-end appliances such as mobile phones and laptops. ${ }^{[4]}$ Hence, even though various technologies have been considered to store renewable energy for long periods of time, the robustness, reliability and cost still remain challenges for these energy systems. ${ }^{[4]}$ In contrast, metal hydrides and complex hydrides have much higher energy densities in the form of hydrogen, and thus they are potentially a more promising energy storage solution for large-scale applications.

The concept of the hydrogen economy was revived around 50 years ago with the aim of replacing gasoline with hydrogen to supply energy to the industry. ${ }^{[5,6]}$ Nowadays, it is more understood as a mean for storing and exporting renewable energy in the form of hydrogen on a relatively large scale. ${ }^{[7]}$ Currently, the majority of hydrogen is produced via petroleum gas or fossil fuel reforming, while water electrolysis from renewable energy is believed to be the most promising and environmentally friendly mean to generate hydrogen. ${ }^{[8]}$ Once produced, hydrogen can then be stored and transported to different applications where it can be released and combusted in fuel cells or engines. Since the early work in the 1920's on hydrogen combustion engines by Erren, ${ }^{[9]}$ the technology has been significantly advanced, ${ }^{[10]}$ while the cost per $\mathrm{kW}$ of fuel cells has drastically decreased from $\$ 275 / \mathrm{kW}$ in 2002 to $\$ 49 / \mathrm{kW}$ in 2011. ${ }^{[11]}$ The main by-product of hydrogen combustion is water and this can be recycled to generate more hydrogen.

Various materials can be used to store hydrogen; however, the bottleneck remains the high temperature and/or pressure for the uptake and release of hydrogen from materials with high hydrogen density. Ideally, hydrogen uptake/release should happen in a narrow temperature range of 0 to $100{ }^{\circ} \mathrm{C}$ and at pressures between 1 and $10 \mathrm{MPa} .{ }^{[8]}$ Hydrogen can also be adsorbed at a solid surface via Van der Waals forces and thus via physisorption at cryogenic temperatures. ${ }^{[12]}$ Various materials including activated carbons, nanocarbons, zeolites and metal organic frameworks have been investigated for this purpose, owing to their high surface areas. ${ }^{[13-15]}$ However, the amount of hydrogen captured on these materials is too small at the ambient to meet the criteria of high hydrogen densities ( $>5$ mass $\% \mathrm{H}_{2}$ at the system level). Indeed, theoretical calculations showed that the maximum hydrogen that can be reversibly stored on carbon materials is 2 mass $\%$ at an extreme low temperature of $-196{ }^{\circ} \mathrm{C} \cdot{ }^{[16-18]}$ Hence, materials forming bonds (ionic or covalent) with hydrogen remains currently a more favourable option for the storage of hydrogen with high density.

The concept of using materials for hydrogen storage arises from the initial discovery of hydrogen absorption in palladium (Pd) in 1866 by Graham. ${ }^{[19]}$ It was reported that Pd could absorb 900 times its own volume of hydrogen at room temperature and atmospheric pressure through the formation of palladium hydride $\left(\mathrm{PdH}_{x}\right){ }^{[20]} \mathrm{With}$ the discovery of $\mathrm{LaNi}_{5}{ }^{[21]}$ and $\mathrm{FeTi}_{5}{ }^{[22]}$ in the 1970's, significant efforts have then been made to develop alloys with a higher hydrogen capacity, i.e., >2 mass \% $\mathrm{H}_{2}{ }^{[23-26]}$

Metal hydrides are believed to be good hydrogen sorption materials, since the chemical bond between metal and hydrogen generally results in a high volumetric hydrogen density (up to $\sim 12$ mass $\% \mathrm{H}_{2}$ ), ${ }^{[18]}$ compared to other traditional storage methods including compressed gas $\left(\sim 5.5\right.$ mass $\left.\% \mathrm{H}_{2}\right)$ and liquid hydrogen $\left(\sim 10\right.$ mass $^{2} \mathrm{H}_{2}$ ) (Figure 2$)$. However, when hydrogen is released from these hydrides, energy is often required due to the endothermic nature of their decomposition reaction into the metal and gaseous hydrogen. For example, $\mathrm{MgH}_{2}$ has a capacity of 7.6 mass $\%$ and releases hydrogen at $>300{ }^{\circ} \mathrm{C}$ and 0.1 $\mathrm{MPa}$ hydrogen pressure. ${ }^{[26]}$ Different approaches have been investigated to reduce the hydrogen desorption temperature from $\mathrm{Mg}$. This includes alloying Mg with other elements and/or nanostructuring approaches in an attempt to modify its enthalpy of reaction with hydrogen. ${ }^{[27-29]}$

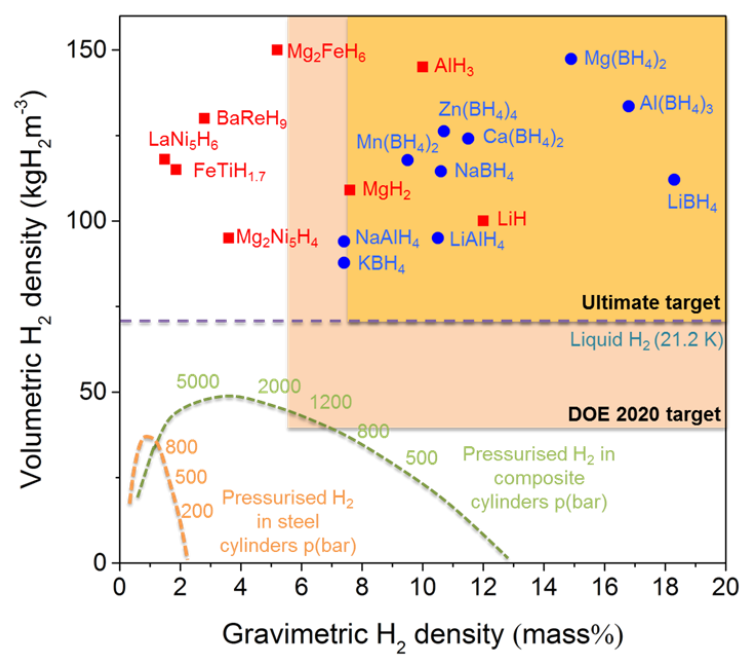

Figure 2 Volumetric and gravimetric hydrogen density of some selected intermetallic and complex hydrides.

Intermetallics $\left(\mathrm{AB}_{x} \mathrm{H}_{n}\right.$, where $x=0.5,1,2$ or 5$)$ have also been widely studied due to their ability to absorb and desorb hydrogen at room temperature and atmospheric pressure. They contain two basic elements where: (i) $\mathrm{A}$, is a rare earth or alkaline earth metal, and (ii) $B$, is a transition metal. The element $A$ has usually a high affinity for hydrogen and can form a stable hydride with a high storage capacity. The transition element $B$ forming an unstable hydride is often used to facilitate hydrogen reversibility from $A .{ }^{[18,27,28]} A$ major drawback of intermetallics remains the limitation of their gravimetric hydrogen density (up to $3 \mathrm{mass} \%$ ), due to the large atomic weight of the elements involved. For example, the well-known $\mathrm{LaNi}_{5} \mathrm{H}_{6}$ has only a gravimetric density of 1.4 mass $\%$.

\section{Hydrogen storage properties of pristine boro- hydrides}

As a result, complex hydrides, such as alanates, amides and borohydrides, have gained increasing attention as hydrogen storage materials over the past decades owing to the potential of reaching much higher hydrogen storage capacities as compared to intermetallics (Table 1). For example, borohydrides can display hydrogen storage capacities reaching 18.3 mass $\%$ and thus have been the focus of many investigations. ${ }^{[30]}$ In borohydrides, hydrogen atoms are attached to boron in the form of a complex anion, i.e., $\left[\mathrm{BH}_{4}\right]^{-}$involving a strong covalent bond. This complex anion is then stabilized with an alkali or alkaline earth element, e.g., $\mathrm{Li}, \mathrm{Na}, \mathrm{Mg}$ and $\mathrm{Ca}^{[31]}$

The challenges of using borohydrides as hydrogen storage materials remain in their slow hydrogen desorption kinetics and the high temperatures required to release hydrogen from their structure. ${ }^{[32]}$ Furthermore, the release of hydrogen from borohydrides occurs usually along several decomposition steps, 


\section{General Chemistry}

Table 1 Hydrogen storage properties of different complex borohydrides $^{[33,34,37,39,40,49,50,54,89,144,150-153]}$

\begin{tabular}{ccccccc}
\hline & $\begin{array}{c}\mathrm{H}_{2} \\
\mathrm{mass} \%\end{array}$ & $\begin{array}{c}M_{\mathrm{p}} \\
{ }^{\circ} \mathrm{C}\end{array}$ & $\begin{array}{c}T_{\mathrm{d}} / \\
{ }^{\circ} \mathrm{C}\end{array}$ & $\begin{array}{c}\Delta H_{\mathrm{f}} /\left(\mathrm{kJ} \cdot \mathrm{mol}^{-1}\right. \\
\left.\mathrm{H}_{2} \text { or }{ }^{*} \mathrm{BH}_{4}\right)\end{array}$ & $\begin{array}{c}-\Delta H_{\text {des }} / \\
\left(\mathrm{kJ} \cdot \mathrm{mol}^{-1}\right. \\
\left.\mathrm{H}_{2}\right)\end{array}$ & $\begin{array}{c}\Delta S /\left(\mathrm{J} \cdot \mathrm{K}^{-1}\right. \\
\left.\mathrm{mol}^{-1} \mathrm{H}_{2}\right)\end{array}$ \\
\hline $\mathrm{LiBH}_{4}$ & 18.3 & 284 & 380 & $\sim-180$ & $56-75$ & $76-238$ \\
$\mathrm{NaBH}_{4}$ & 10.6 & 505 & 565 & $\sim-190$ & $90-108$ & $101-133$ \\
$\mathrm{KBH}_{4}$ & 7.4 & 500 & 584 & $\sim-230$ & - & $106-162$ \\
$\mathrm{Mg}\left(\mathrm{BH}_{4}\right)_{2}$ & 14.9 & 320 & 320 & $-99^{*}$ & $39-57$ & $91-128$ \\
$\mathrm{Ca}\left(\mathrm{BH}_{4}\right)_{2}$ & 11.5 & 320 & 347 & $-151^{*}$ & $75.5-87$ & 158 \\
$\mathrm{Zn}\left(\mathrm{BH}_{4}\right)_{2}$ & 8.4 & 85 & 85 & $-18^{*}$ & - & - \\
$\mathrm{Sc}\left(\mathrm{BH}_{4}\right)_{3}$ & 13.5 & - & 260 & $-106^{*}$ & - & - \\
$\mathrm{Al}\left(\mathrm{BH}_{4}\right)_{3}$ & 16.9 & -64 & 44.5 & -301.8 & 6 & 289 \\
$\mathrm{Zr}\left(\mathrm{BH}_{4}\right)_{4}$ & 10.7 & - & 250 & $-87^{*}$ & - & - \\
\hline
\end{tabular}

which was initially simplified as: ${ }^{[33]}$

$$
\mathrm{M}\left(\mathrm{BH}_{4}\right) \rightarrow \mathrm{MH}+\mathrm{B}+3 / 2 \mathrm{H}_{2}
$$

The experimental Pressure-Composition-Temperature (PCT) curve of pristine $\mathrm{LiBH}_{4}$ showed only 8.5 to 10.6 mass\% hydrogen releases in the temperature range of $424-517{ }^{\circ} \mathrm{C}$ (Figure 3a), while its theoretical hydrogen storage capacity is 18.3 mass $\%$. This may be explained by the partial decomposition of $\mathrm{LiBH}_{4}$ into $\mathrm{B}$ and $\mathrm{LiH}$ (decomposition temperature $>700$ ${ }^{\circ} \mathrm{C}$ ), which corresponds to a theoretical capacity of 13.9 mass $\%{ }^{[33]}$

$$
\mathrm{LiBH}_{4} \rightarrow \mathrm{LiH}+\mathrm{B}+3 / 2 \mathrm{H}_{2}
$$
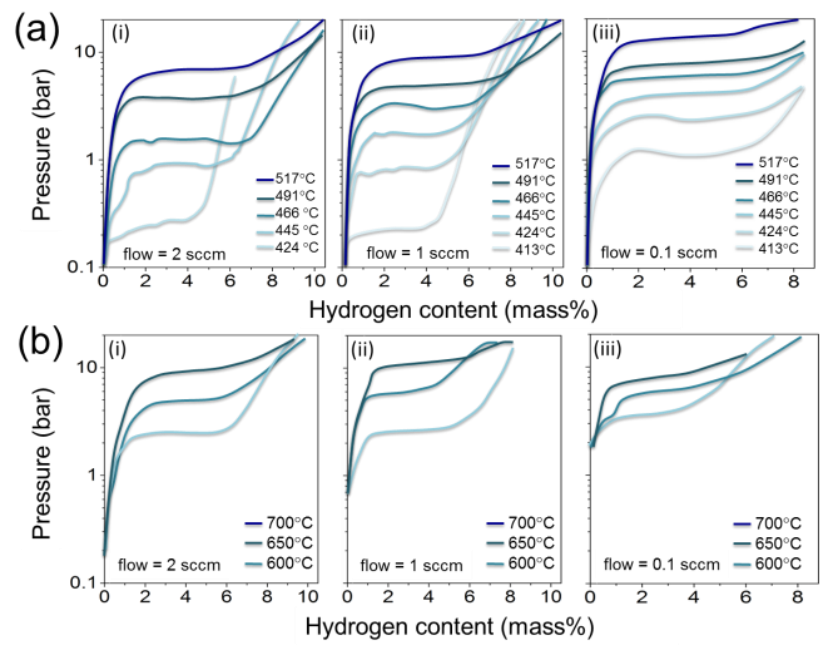

Figure 3 Pressure-composition-temperature curves of (a) $\mathrm{LiBH}_{4}$ and (b) $\mathrm{NaBH}_{4}$ measured at different hydrogen flow. ${ }^{[3,165]}$

Despite the multi-decomposition path of $\mathrm{LiBH}_{4},{ }^{[34-36]}$ a single plateau was observed across all desorption temperatures. However, the equilibrium pressure was too low $(0.02-1 \mathrm{MPa})$ for any practical application. Additionally, it was found that the equilibrium plateau pressure is dependent on the experimental conditions (e.g., the hydrogen flow), indicating that the kinetics of $\mathrm{LiBH}_{4}$ is slow. This also explains the single plateau observed. From these PCT measurements, a dehydrogenation enthalpy of $74 \mathrm{~kJ} \cdot \mathrm{mol}^{-1} \mathrm{H}_{2}$ and entropy of $115 \mathrm{~J} \cdot \mathrm{K}^{-1} \cdot \mathrm{mol}^{-1} \mathrm{H}_{2}$ were determined, ${ }^{[37]}$ and these values are slightly higher than the re- ported literature values of $56-68.9 \mathrm{~kJ} \cdot \mathrm{mol}^{-1} \mathrm{H}_{2}$ and $97.4-$ $100.3 \mathrm{~J} \cdot \mathrm{K}^{-1} \cdot \mathrm{mol}^{-1} \mathrm{H}_{2}{ }^{[38-40]}$ Moreover, the decomposition of $\mathrm{LiBH}_{4}$ is accompanied with a high activation energy barrier $\left(59 \pm 2 \mathrm{~kJ} \cdot \mathrm{mol}^{-1}\right),{ }^{[41]}$ due to the need of achieving significant mass transport of ionic species including $\left(\mathrm{BH}_{4}\right)^{-}$, and thus the melting of the hydride before significant hydrogen release can occur. ${ }^{[42]}$ The hydrogen reversibility of borohydrides is also considered hampered by the loss of boron in the form of $\mathrm{B}_{x} \mathrm{H}_{y}$ compounds and the extensive elemental disproportionation during hydrogen release. $\mathrm{LiBH}_{4}$ can be regenerated from $\mathrm{LiH}$ and $\mathrm{B}$, to some extent under $35 \mathrm{MPa} \mathrm{H}_{2}$ pressure at $600{ }^{\circ} \mathrm{C},{ }^{[43]}$ or at a lower hydrogen pressure of $15 \mathrm{MPa}$ at $727^{\circ} \mathrm{C} .{ }^{[35]}$

As shown in Figure 3b, the PCT curve of $\mathrm{NaBH}_{4}$ in the temperature range of 600 to $700{ }^{\circ} \mathrm{C}$ also shows a single equilibrium plateau pressure, indicative of a one-step decomposition path, although it is known that the thermal decomposition of $\mathrm{NaBH}_{4}$ is a multi-step process. ${ }^{[4]}$ Moreover, a higher hydrogen flow resulted in a lower plateau pressure and this further indicated the slow kinetics of $\mathrm{NaBH}_{4}$ decomposition. The dehydrogenation enthalpy and entropy determined from these experimental PCT curves were $-108 \mathrm{~kJ} \cdot \mathrm{mol}^{-1} \mathrm{H}_{2}$ and 133 $\mathrm{J} \cdot \mathrm{K}^{-1} \cdot \mathrm{mol}^{-1} \mathrm{H}_{2}$, respectively. They implied a decomposition temperature of $534{ }^{\circ} \mathrm{C}$ for $\mathrm{NaBH}_{4}$ at a pressure of $0.1 \mathrm{MPa}$. Partial hydrogen reversibility was achieved from $\mathrm{NaH}$ and $\mathrm{B}$ mixtures under 17.3 $\mathrm{MPa}$ hydrogen pressure at $400{ }^{\circ} \mathrm{C}$ for 24 h. ${ }^{[45]}$

The decomposition of alkaline earth borohydrides is more complicated and follows the reaction path (3), e.g., for $\mathrm{Mg}\left(\mathrm{BH}_{4}\right)_{2}{ }^{[46]}$ or $(4)$, e.g., for $\mathrm{Ca}\left(\mathrm{BH}_{4}\right)_{2}::^{[47,48]}$

$$
\begin{aligned}
& \mathrm{M}\left(\mathrm{BH}_{4}\right)_{2} \rightarrow \mathrm{MH}_{2}+2 \mathrm{~B}+3 \mathrm{H}_{2} \\
& \mathrm{M}\left(\mathrm{BH}_{4}\right)_{2} \rightarrow 2 / 3 \mathrm{MH}_{2}+1 / 3 \mathrm{MB}_{6}+10 / 3 \mathrm{H}_{2}
\end{aligned}
$$

Figure 4a shows the PCT curve of $\mathrm{Mg}\left(\mathrm{BH}_{4}\right)_{2}$ at 290,320 and $350{ }^{\circ} \mathrm{C}$. Two plateaus were observed at high temperatures $\left(350^{\circ} \mathrm{C}\right)$ and at more than $0.1 \mathrm{MPa}$, whereas only one plateau was observed at 290 and $320^{\circ} \mathrm{C}$. At these temperatures, the plateau pressure increased from 1.4 MPa to $3.1 \mathrm{MPa}$, respectively. ${ }^{[49]}$ This indicates that the decomposition path of $\mathrm{Mg}\left(\mathrm{BH}_{4}\right)_{2}$ varies according to the temperature. From the PCT measurements, the dehydrogenation enthalpy and entropy were determined to be of $39.3 \mathrm{~kJ} \cdot \mathrm{mol}^{-1} \mathrm{H}_{2}$ and $91.3 \mathrm{~J} \cdot \mathrm{mol}^{-1} \cdot \mathrm{K}^{-1} \mathrm{H}_{2}$, respectively. ${ }^{[49]}$ However, direct rehydrogenation of $\mathrm{Mg}\left(\mathrm{BH}_{4}\right)_{2}$ from $\mathrm{Mg}$ and $\mathrm{B}$ led to the formation of $\mathrm{MgB}_{12} \mathrm{H}_{12}$ and this can be understood by the difficulty of breaking the $\mathrm{B}-\mathrm{B}$ bonds in the icosahedral cluster of $\mathrm{B}$ to form $\left(\mathrm{BH}_{4}\right)^{-[50]}$ Nevertheless, starting from $\mathrm{MgB}_{2}, \mathrm{Mg}\left(\mathrm{BH}_{4}\right)_{2}$ was synthesized after a few days under a hydrogen pressure of $90 \mathrm{MPa}$ at $400{ }^{\circ} \mathrm{C} . .^{[51-53]}$ (a)

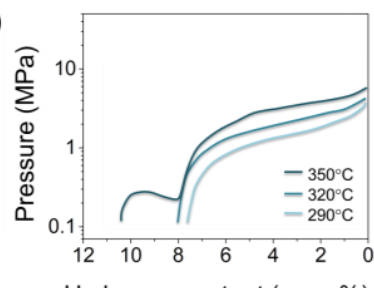

Hydrogen content (mass\%)

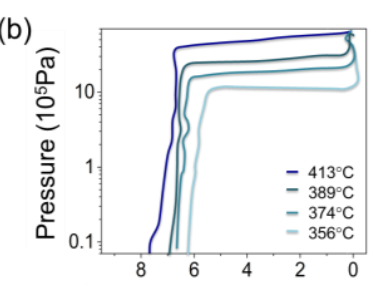

Hydrogen content (mass \%)
Figure 4 (a) PCT curves for desorption of $\mathrm{LiBH}_{4}$ and $\mathrm{MgCl}_{2}$ mixture at $290,320,350{ }^{\circ} \mathrm{C} .^{[49]}$ (b) PCT curves of $\mathrm{Ca}\left(\mathrm{BH}_{4}\right)_{2}$ at $356,374,389$, and $413^{\circ} \mathrm{C} .^{[54]}$

A similar observation was made on the isotherm of $\mathrm{Ca}\left(\mathrm{BH}_{4}\right)_{2}$ (Figure $\left.4 \mathrm{~b}\right)$. One plateau $(1.1 \mathrm{MPa})$ was observed at $356{ }^{\circ} \mathrm{C}$, whereas two plateaus (at 1.5 and $6 \mathrm{MPa}$ ) were ob- 
served at higher tempera-tures range in good agreement with the two-step decom-position reaction of $\mathrm{Ca}\left(\mathrm{BH}_{4}\right)_{2}$ to $\mathrm{CaH}_{2}$. ${ }^{[54]}$ From these measurements, the enthalpy and entropy of the decomposition of the $\mathrm{Ca}\left(\mathrm{BH}_{4}\right)_{2}$ to $\mathrm{CaH}_{2}$ were approximated to be $87 \mathrm{~kJ} \cdot \mathrm{mol}^{-1} \mathrm{H}_{2}$ and $158 \mathrm{~J} \cdot \mathrm{K}^{-1} \cdot \mathrm{mol}^{-1} \mathrm{H}_{2}$. The decomposition of $\mathrm{Ca}\left(\mathrm{BH}_{4}\right)_{2}$ is particularly complex involving polymorphic phase transitions and the formation of unknown intermediate phases. ${ }^{[5,56]}$ Only partial rehydrogenation was observed with the addition of a catalyst at relatively high temperatures and pressures $\left(350-440{ }^{\circ} \mathrm{C}\right.$ and 9-70 $\mathrm{MPa}$ hydrogen pressure). ${ }^{[47,57]}$ Similar to $\mathrm{LiBH}_{4}$, the agglomeration of particles during melting, the formation of stable intermediates such as $\mathrm{CaB}_{12} \mathrm{H}_{12}$, and the release of dodecaborane $\left(\mathrm{B}_{12} \mathrm{H}_{12}\right)$ during the hydrogen desorption remain still the significant problems restricting reversibility. ${ }^{[58]}$ As such, pristine borohydrides are not viable materials for hydrogen storage application.

\section{Past and current investigations in borohydrides}

Following the approach of Bogdanović and Schwickardi around late 1990s to improve the hydrogen desorption and reversibility of alanates, ${ }^{[59]}$ various doping strategies have been investigated with borohydrides.

This includes the stabilization/destabilization strategy, which involves the combination of a borohydride with a second hydride (known as reactive hydride composites) in order to lower the decomposition temperature, simplify the dehydrogenation paths and stabilize a decomposition product more prone to facilitate the hydrogen reversibility of the material. ${ }^{[31,60-66]} A$ catalyst may be added to this process in order to improve the reaction kinetics. ${ }^{[67]}$ For example, the combination of $\mathrm{LiBH}_{4}$ and $\mathrm{MgH}_{2}$ led to a decomposition enthalpy that is reduced to 45.8 $\mathrm{kJ} \cdot \mathrm{mol}^{-1} \mathrm{H}_{2}$ and thus a potential desorption temperature of $225^{\circ} \mathrm{C}$ at a hydrogen equilibrium pressure of $0.1 \mathrm{MPa}$, due to the formation of $\mathrm{MgB}_{2}$ following: : $^{[68]}$

$$
2 \mathrm{LiBH}_{4}+\mathrm{MgH}_{2} \rightarrow 2 \mathrm{LiH}+\mathrm{MgB}_{2}+4 \mathrm{H}_{2}
$$

However, the decomposition path of such reactive hydride mixture is highly dependent on the experimental conditions. For example, $0.3 \mathrm{LiBH}_{4}+\mathrm{MgH}_{2}$ decomposes under dynamic vacuum as following: ${ }^{[69-72]}$

$$
\begin{aligned}
& 0.3 \mathrm{LiBH}_{4}+\mathrm{MgH}_{2} \rightarrow 0.3 \mathrm{LiBH}_{4}+\mathrm{Mg}+\mathrm{H}_{2} \\
& 0.3 \mathrm{LiBH}_{4}+\mathrm{Mg}+\mathrm{H}_{2} \rightarrow 0.78 \mathrm{Mg}_{0.816} \mathrm{Li}_{0.184}+0.52 \mathrm{Mg}_{0.70} \mathrm{Li}_{0.30}+ \\
& 0.3 \mathrm{~B}+1.60 \mathrm{H}_{2}
\end{aligned}
$$

While under a hydrogen back-pressure $\mathrm{MgB}_{2}$ is formed from the decomposition of $2 \mathrm{LiBH}_{4}+\mathrm{MgH}_{2}$ following the two-step reaction mechanism (8 and 9$).{ }^{[73-75]}$

$$
\begin{aligned}
& 2 \mathrm{LiBH}_{4}+\mathrm{MgH}_{2} \rightarrow 2 \mathrm{LiBH}_{4}+\mathrm{Mg}+\mathrm{H}_{2} \\
& 2 \mathrm{LiBH}_{4}+\mathrm{Mg}+\mathrm{H}_{2} \rightarrow 2 \mathrm{LiH}+\mathrm{MgB}_{2}+4 \mathrm{H}_{2}
\end{aligned}
$$

The mixture $\mathrm{LiBH}_{4}-\mathrm{Al}$ was also found to reversibly store hydrogen at $400-450{ }^{\circ} \mathrm{C}$ with a similar reaction mechanism. ${ }^{\text {[6] }}$ $\mathrm{LiBH}_{4}-\mathrm{LiNH}_{2}$ and $\mathrm{LiNH}_{2}-\mathrm{MgH}_{2}-\mathrm{LiBH}_{4}$ mixtures have also been investigated. ${ }^{[77-80]} \mathrm{LiBH}_{4}-\mathrm{LiNH}_{2}$ in a $1: 2$ ratio forms the quaternary hydride $\mathrm{Li}_{3} \mathrm{BN}_{2} \mathrm{H}_{8}$. This new hydride has a theoretical hydrogen capacity of 11.9 mass $\%$ and is able to release 10 mass $\%$ hydrogen at temperatures above $250{ }^{\circ} \mathrm{C} .{ }^{[77]} \mathrm{LiNH}_{2}$, $\mathrm{MgH}_{2}$ and $\mathrm{LiBH}_{4}$ have also been mixed in different ratios, and this led to different hydrogen capacities and reversibility. For example, 8.6 mass $\%$ hydrogen is desorbed and 3.5 mass $\%$ is absorbed back at $180{ }^{\circ} \mathrm{C}$ with the $\left(\mathrm{LiNH}_{2}\right)_{2}-\left(\mathrm{MgH}_{2}\right)_{0.5}-\left(\mathrm{LiBH}_{4}\right)_{1}$ mixture. ${ }^{[80]}$

Recent investigations revealed that the structure and bonding of borohydride compounds depend upon the electronegativities of the metal cation, ${ }^{[31,40]}$ and the hydrogen desorption temperature is linearly correlated to the Pauling electronegativity of the metal cation (Figure $5 \mathrm{a}$ ). ${ }^{[81]}$ Therefore, the idea of mixed borohydrides, such as $\mathrm{MLi}\left(\mathrm{BH}_{4}\right)_{n}$, where $\mathrm{M}$ and $\mathrm{Li}$ have a significant electronegativity difference, has been investigated owing to the potential of improved thermodynamic stability. The synthesis of such bimetallic borohydrides can simply be performed by physical milling (mechanochemical synthesis) ${ }^{[82-86]}$ or wet chemistry. ${ }^{[87,88]}$ Moreover, substitution of a cation in borohydrides not only results in a reduced hydrogen release temperature but also leads to a modification of their melting behaviour. As shown in Figure 5b, the melting point of the mixed borohydrides decreases as the dehydrogenation temperature is reduced. Further reaction between borohydrides and ammonia ${ }^{[89]}$ can lead to the combination of $\mathrm{H}^{\delta^{+}}$and $\mathrm{H}^{\delta_{-}^{-}}$and lead to a destabilised system with a higher storage capacity and lower temperatures for hydrogen release. ${ }^{[88,90-94]}$ Some common mixed-cations borohydrides and their hydrogen storage properties are summarised in Table 2.
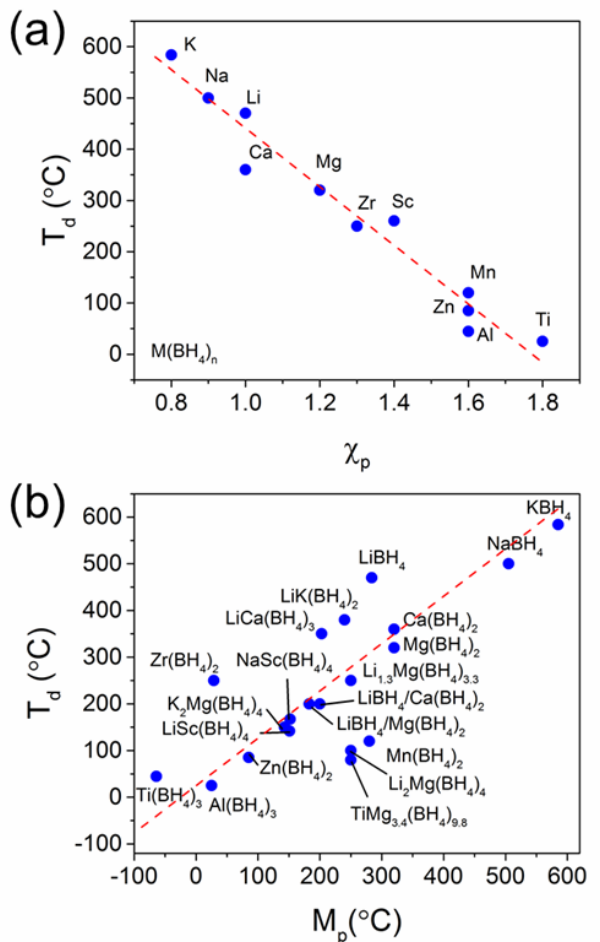

Figure 5 (a) Relation between the desorption temperature $\left(T_{\mathrm{d}}\right)$, and the Pauling electronegativities of cations $\left(\chi_{\mathrm{p}}\right)$. (b) Relation between the melting point $\left(M_{\mathrm{p}}\right)$ and decomposition temperature $\left(T_{\mathrm{d}}\right)$.

Catalysts are often used to modify the hydrogen desorption and absorption kinetics. Several materials, such as $\mathrm{Mg}$ and $\mathrm{TiCl}_{3}$ have been claimed to be good catalysts. ${ }^{[67]}$ For instance, the hydrogen storage properties of $\mathrm{LiBH}_{4}-\mathrm{MgH}_{2}$ are often modified via addition of other types of metal oxides and halides, such as $\mathrm{Nb}_{2} \mathrm{O}_{5}$ and $\mathrm{TiCl}_{3}{ }^{[67]}$ However, these additives are often wrongly termed catalysts, because they react generally with borohydrides through metathesis routes. ${ }^{\left[{ }^{95]}\right.}$ The enhanced hydrogen desorption temperature is then due to the exothermic nature of the metathesis reaction as well as the effective dispersion of the "catalyst" within the borohydride phase. Additional formation of less stable intermediate metal borohydrides 
Table 2 Hydrogen storage properties of mixed borohydrides

\begin{tabular}{|c|c|c|c|c|c|}
\hline & $\begin{array}{c}\mathrm{H}_{2} \text { content/ } \\
\text { (mass } \%)\end{array}$ & $T_{\mathrm{d}} /{ }^{\circ} \mathrm{C}$ & $M p /{ }^{\circ} \mathrm{C}$ & Reversibility $T$ and $P$ & Ref. \\
\hline $\mathrm{LiK}\left(\mathrm{BH}_{4}\right)_{2}$ & - & 380 & 240 & - & {$[154]$} \\
\hline $\mathrm{Li}_{1.5} \mathrm{M}_{0.5}\left(\mathrm{BH}_{4}\right)_{3}(\mathrm{M}=\mathrm{Ti}, \mathrm{Fe}, \mathrm{Cr})$ & $3-6$ & $450-600$ & - & $450-600^{\circ} \mathrm{C}, 100-120$ bar & [87] \\
\hline $\mathrm{LiMg}_{0.5}\left(\mathrm{BH}_{4}\right)_{2}$ & 2.5 & 500 & - & $500^{\circ} \mathrm{C}, 80$ bar & [87] \\
\hline $\mathrm{LiBH}_{4} / \mathrm{Mg}\left(\mathrm{BH}_{4}\right)_{2}$ & 2.5 & $240-500$ & 183 & $400^{\circ} \mathrm{C}, 100 \mathrm{bar}$ & [155] \\
\hline $\mathrm{Li}_{n} \mathrm{Mg}\left(\mathrm{BH}_{4}\right)_{y}$ & - & $\begin{array}{l}80-500 \\
250-500\end{array}$ & - & - & {$[87]$} \\
\hline $\mathrm{LiBH}_{4} / \mathrm{Ca}\left(\mathrm{BH}_{4}\right)_{2}$ & 4 & $200-500$ & 200 & $400^{\circ} \mathrm{C}, 120 \mathrm{bar}$ & {$[156]$} \\
\hline $\mathrm{LiCa}\left(\mathrm{BH}_{4}\right)_{3}$ & 5.3 & $200-500$ & 203 & $400^{\circ} \mathrm{C}, 100$ bar & [155] \\
\hline $\mathrm{ZrLi}\left(\mathrm{BH}_{4}\right)_{5}$ & - & $322-600$ & - & - & {$[81]$} \\
\hline $\mathrm{ZrLi}\left(\mathrm{BH}_{4}\right)_{6}$ & - & $377-600$ & - & - & [81] \\
\hline \multirow[t]{3}{*}{$\mathrm{LiSc}\left(\mathrm{BH}_{4}\right)_{4}$} & - & $142-400$ & 151 & $400^{\circ} \mathrm{C}$ & {$[82,156]$} \\
\hline & - & $142-262$ & 152 & - & \\
\hline & - & $80-330$ & - & $250^{\circ} \mathrm{C}, 120$ bar & [157] \\
\hline $\mathrm{LiZn}_{2}\left(\mathrm{BH}_{4}\right)_{5}$ & - & $121-127$ & - & - & {$[83,158]$} \\
\hline $\mathrm{Li}_{3} \mathrm{MZn}_{5}\left(\mathrm{BH}_{4}\right)_{15}$ & - & - & - & - & \\
\hline $\mathrm{MY}\left(\mathrm{BH}_{4}\right)_{4}(\mathrm{M}=\mathrm{Li}, \mathrm{Na})$ & - & 25 & - & - & \\
\hline $\mathrm{NaK}\left(\mathrm{BH}_{4}\right)_{2}$ & - & - & - & - & [159] \\
\hline $\mathrm{Na}_{2} \mathrm{Mn}\left(\mathrm{BH}_{4}\right)_{4}$ & - & $120-150$ & - & - & {$[160]$} \\
\hline $\mathrm{NaZn}_{2}\left(\mathrm{BH}_{4}\right)_{5}$ & - & 95 & - & - & {$[83]$} \\
\hline $\mathrm{NaZn}\left(\mathrm{BH}_{4}\right)_{3}$ & - & 103 & - & - & [83] \\
\hline $\mathrm{NaZn}(\mathrm{BH} 4)_{3}$ & - & $80-200$ & - & - & [88] \\
\hline $\mathrm{NaZn}(\mathrm{BH} 4)_{3} \cdot \mathrm{NH}_{3}$ & - & $80-150$ & - & - & [88] \\
\hline $\mathrm{NaZn}(\mathrm{BH} 4)_{3} \cdot 2 \mathrm{NH}_{3} / \mathrm{ZnCl}_{2}$ & - & $90-160$ & - & - & [88] \\
\hline \multirow[t]{2}{*}{$\mathrm{NaSc}\left(\mathrm{BH}_{4}\right)_{4}$} & - & 167 & 152 & - & \\
\hline & - & $80-330$ & & $250^{\circ} \mathrm{C}, 120 \mathrm{bar}$ & [157] \\
\hline \multirow[t]{2}{*}{$\mathrm{KSc}\left(\mathrm{BH}_{4}\right)_{4}$} & - & $187-317$ & 132 & - & \\
\hline & - & $80-330$ & & $250^{\circ} \mathrm{C}, 120 \mathrm{bar}$ & [157] \\
\hline $\mathrm{K}_{2} \mathrm{Mg}\left(\mathrm{BH}_{4}\right)_{4}$ & - & 150 & 143 & - & [161] \\
\hline $\mathrm{K}_{3} \mathrm{Mg}\left(\mathrm{BH}_{4}\right)_{5}$ & - & 191 & 195 & - & [161] \\
\hline $\mathrm{KAl}\left(\mathrm{BH}_{4}\right)_{4}$ & - & $135-175$ & - & - & {$[162,163]$} \\
\hline $\mathrm{K}_{2} \mathrm{Mn}\left(\mathrm{BH}_{4}\right)_{4}$ & - & 147 & - & - & {$[161]$} \\
\hline $\mathrm{Mn}\left(\mathrm{BH}_{4}\right)_{2} / \mathrm{MBH}_{4}(\mathrm{M}=\mathrm{Li}, \mathrm{Na}, \mathrm{Mg})$ & - & $83-117$ & - & - & {$[164]$} \\
\hline $\mathrm{M}\left[\left(\mathrm{Y}\left(\mathrm{BH}_{4}\right)_{4}\right](\mathrm{M}=\mathrm{Li}, \mathrm{Na}, \mathrm{K}, \mathrm{Cs}, \mathrm{Cs})\right.$ & - & $<350$ & - & - & - \\
\hline
\end{tabular}

can also lead to a reduced hydrogen release temperature. For example, it has been claimed that $\mathrm{NiCl}_{2}$ and $\mathrm{FeCl}_{2}$ had an significant catalytic influence on the destabilisation of lithium borohydride due to the formation of a new metallic borohydride, i.e., $\mathrm{Ni}\left(\mathrm{BH}_{4}\right)_{2}$ and $\mathrm{Fe}\left(\mathrm{BH}_{4}\right)_{2}$, respectively. ${ }^{[96,97]}$ Initial addition of these two chlorides reduced the dehydrogenation temperature below $300^{\circ} \mathrm{C}$, while extended ball milling further decreased the temperature to $250{ }^{\circ} \mathrm{C} .^{[96]}$ Metallic nickel has also been considered. For example, Xia et al. ${ }^{[98]}$ reported that ball milling $\mathrm{Ni}$ powder with $\mathrm{LiBH}_{4}$ can result in faster hydrogen desorption kinetics and the release of most of the hydrogen below $600{ }^{\circ} \mathrm{C}$. Fast sorption kinetics under moderate conditions $\left(320{ }^{\circ} \mathrm{C}, 4\right.$ $\mathrm{MPa} \mathrm{H}_{2}$ pressure) were also achieved for nanoconfined $\mathrm{LiBH}_{4}$ in a carbon mesostructure after addition of $\mathrm{Ni}$, according to Ngene et al. ${ }^{[99,100]}$ However, other reports showed a negative influence of $\mathrm{Ni}$ on the hydrogen storage properties of $\mathrm{LiBH}_{4}{ }^{[101]}$

\section{Nanoconfinement of complex borohydrides}

As discussed above, the approach of reactive hydrides or additives can only improve the hydrogen uptake and release from borohydrides to a certain extent. A high temperature is still required to enable fast ionic diffusion and the recombination of the stable dehydrogenation products to achieve hydrogen reversibility. Another approach is via nanoconfinement, i.e., a reduction of the particle size of the active material down to the nanoscale regimes. ${ }^{[102]}$ Through this approach, it is believed that both the thermodynamics and kinetics of hydrides can be modified. However, it is still difficult to explain comprehensively the nature of the improvements observed by nanoconfinement to date. The following section will discuss the thermodynamic and kinetic impacts of nanoconfinement on the hydrogen properties of complex hydrides.

\section{Thermodynamic considerations}

Nanoscale materials have generally very different thermal stabilities compared to their bulk counterparts. Reducing the particle size to nanoscale can significantly increase the surface area and thus result in significant changes in surface energy. In the case of hydrides, this can either result in a stabilisation or destabilisation. ${ }^{[103]}$

For a metal/hydrogen system:

$$
\mathrm{M}+\mathrm{H}_{2} \rightarrow \mathrm{MH}_{2}
$$

Berube et al..$^{[104]}$ related the change in Gibbs free energy to the surface energy as shown below.

$$
\Delta G=\Delta G_{0}+R T \ln \left(p / p_{0}\right)+\left(3 V_{\mathrm{m}} \Delta M \rightarrow \mathrm{MH}_{2}(\gamma, r)\right) / r
$$

where $r$ corresponds to the particle size, $p$ to the pressure, $R$ the universal gas constant, $T$ the temperature, $V_{m}$ the molar volume of metal or hydride phase, $\gamma$ the nanoparticle surface energy, and $\Delta_{\mathrm{M} \rightarrow \mathrm{MH} 2}$ the variation in surface energy as the ma- 
terial transitions from the metallic to the hydride phase.

Under equilibrium conditions (i.e., $\Delta G=0$ ), the increase in surface energy can affect the thermodynamic stability of the hydrides and increase the hydrogen release rate by changing the equilibrium hydrogen pressure $\left(P_{\mathrm{eq}}\right){ }^{[105]}$

$$
\ln P_{\text {eq }}=1 / R T\left(\Delta H_{0}+\left(3 V_{\mathrm{m}} \Delta M \rightarrow \mathrm{MH}_{2}(\gamma, r)\right) / r\right)-\Delta S / R
$$

Theoretical calculations showed that metal hydride particles with sizes less than $3 \mathrm{~nm}$ could experience a thermodynamic modification to their properties. ${ }^{[106-109]}$ For instance, a $20 \%$ decrease of enthalpy was achieved with a particle size of $5 \mathrm{~nm}$ for $\mathrm{MgH}_{2}{ }^{[104]}$

It is known that particle size reduction can create structural rearrangement and change in atomic distance. ${ }^{[103]}$ This was previously observed for nanoconfined $\mathrm{NaAlH}_{4}$ using inelastic neutron scattering and Raman spectroscopy, where vibrational transitions were found to be broader and the librational modes and lattice bands shifted towards lower energies. ${ }^{[110]}$ In complex hydrides, if the distance between the cations and anions is shortened upon the local "stress" imposed by nanoconfinement, the strength of the anion bonds (e.g., Al-H and $\mathrm{B}-\mathrm{H}$ ) will be weakened, leading to a lower hydrogen release temperature and increase in equilibrium pressure ${ }^{[97,103]}$ Accordingly, nanoconfinement can also result in thermodynamic changes for complex hydrides. ${ }^{[103]} \mathrm{A}$ decrease in both equilibrium pressure and enthalpy were observed for nanoconfined $\mathrm{NaAlH}_{4}{ }^{[111]}$

As previously discussed, the decomposition paths for complex hydrides are generally complicated and involve multiple steps. Bulk $\mathrm{NaAlH}_{4}$ and catalysed $\mathrm{NaAlH}_{4}$ decompose via two steps:

$$
\begin{aligned}
& \mathrm{NaAlH}_{4} \rightarrow 1 / 3 \mathrm{Na}_{3} \mathrm{AlH}_{6}+2 / 3 \mathrm{Al}+\mathrm{H}_{2} \\
& 1 / 3 \mathrm{Na}_{3} \mathrm{AlH}_{6} \rightarrow \mathrm{NaH}+1 / 2 \mathrm{H}_{2}
\end{aligned}
$$

In contrast, $\mathrm{NaAlH}_{4}$ confined within an aerogel with a pore size of $\sim 13 \mathrm{~nm}$ appeared to have a single decomposition step. However, XRD showed the formation of $\mathrm{Na}_{3} \mathrm{AlH}_{6}$, and this indicated that nanoconfinement resulted in a significant reduction of the dehydrogenation enthalpy and temperature for $\mathrm{Na}_{3} \mathrm{AlH}_{6}$ decomposition. Accordingly, the first step and second reaction step (11 and 12) appeared upon nanoconfinement as unresolved steps. On the other hand, $\mathrm{NaAlH}_{4}$ confined in smaller pore sizes $(2-3 \mathrm{~nm})$ showed no formation of $\mathrm{Na}_{3} \mathrm{AlH}_{6},{ }^{[112]}$ suggesting that nanoconfinement can further modify the thermodynamic stability of $\mathrm{NaAlH}_{4}$ and $\mathrm{Na}_{3} \mathrm{AlH}_{6}$. A similar conclusion was also drawn from theoretical modelling by Majzoub et al. ${ }^{[113]}$ who reported that $\left[\mathrm{AlH}_{6}\right]^{3-}$ anions of $\mathrm{Na}_{3} \mathrm{AlH}_{6}$ became unstable due to Jahn-Teller distortions for particle sizes in the range of 1.5 to $2 \mathrm{~nm}$. The thermodynamic effect of nanoconfinement of $\mathrm{NaAlH}_{4}$ is summarised in Figure 6. It can thus be concluded that the effect of nanoconfinement can either increase or decrease the equilibrium pressure depending on the relative effects on the hydrogenated and dehydrogenated states, and lead to different effects on the various decomposition steps of $\mathrm{NaAlH}_{4}$.

For complex borohydrides, an understanding of the thermodynamic effect of nanoconfinement is less established. The influence of nanoconfinement on the equilibrium pressure of $\mathrm{LiBH}_{4}$ incorporated into a carbon aerogel (13 nm pore size) showed an equilibrium pressure of $0.3 \mathrm{MPa}$ at $300^{\circ} \mathrm{C},{ }^{[114]}$ which is consistent with the plateau pressure for the decomposition path following the formation of $\mathrm{Li}_{2} \mathrm{~B}_{12} \mathrm{H}_{12}{ }^{[115]}$

$\mathrm{LiBH}_{4} \rightarrow 5 / 6 \mathrm{LiH}+1 / 12 \mathrm{Li}_{2} \mathrm{~B}_{12} \mathrm{H}_{12}+13 / 12 \mathrm{H}_{2}$

In comparison, $\mathrm{LiBH}_{4}$ mixed physically with nonporous (a)
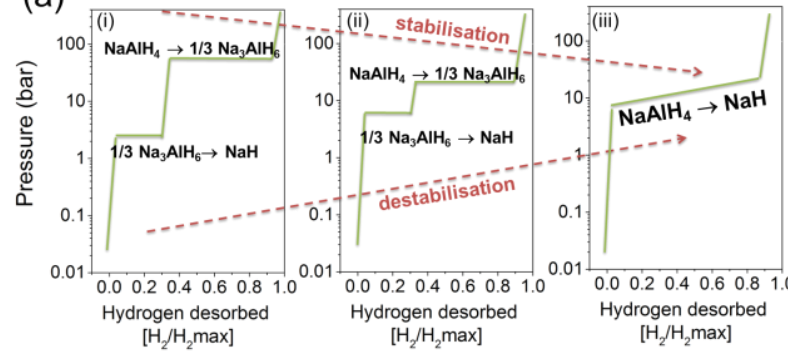

(b)

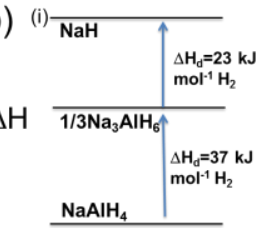
ydrogen desorbed $\left[\mathrm{H}_{2} / \mathrm{H}_{2} \mathrm{max}\right]$

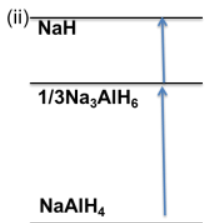

(iii) $\overline{\mathrm{NaH}}$

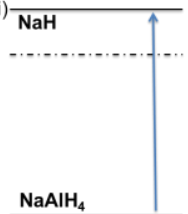

$\mathrm{NaAlH}_{4}$

Figure 6 Schematic diagrams of (a) equilibrium hydrogen pressure isotherms and (b) enthalpy for (i) bulk and (ii) nanoconfined $\mathrm{NaAlH}_{4}$ with slight destabilisation of $\mathrm{Na}_{3} \mathrm{AlH}_{6}$ and (iii) sufficiently nanoconfined of $\mathrm{NaAlH}_{4}{ }^{[111,166]}$

graphite exhibited an equilibrium plateau pressure of 0.03 $\mathrm{MPa},{ }^{[114]}$ indicating that the decomposition of bulk $\mathrm{LiBH}_{4}$ leads to the formation of elemental boron.

$$
\mathrm{LiBH}_{4} \rightarrow \mathrm{LiH}+\mathrm{B}+2 \mathrm{H}_{2}
$$

In fact, as illustrated in Figure 7, the decomposition of $\mathrm{LiBH}_{4}$ via the formation of $\mathrm{Li}_{2} \mathrm{~B}_{12} \mathrm{H}_{12}$ has a lower dehydrogenation enthalpy $\left(56 \mathrm{~kJ} \cdot \mathrm{mol}^{-1} \cdot \mathrm{H}_{2}\right)$ compared to reaction (14). Hence, nanoconfinement may not alter the thermodynamics of $\mathrm{LiBH}_{4}$ but rather modify its decomposition path by forcing the mechanism through the $\mathrm{Li}_{2} \mathrm{~B}_{12} \mathrm{H}_{12}$ route.

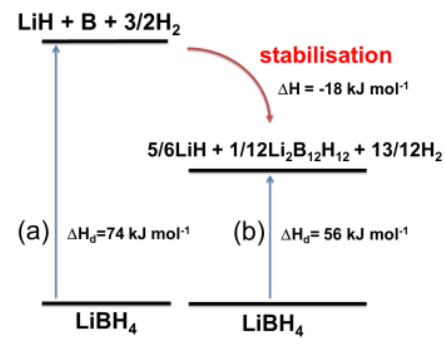

Figure 7 Schematic illustration of the enthalpy of decomposition for (a) bulk $\mathrm{LiBH}_{4}$ and (b) nanoconfined $\mathrm{LiBH}_{4}$ via different decomposition paths. ${ }^{[167]}$

\section{Kinetic considerations}

The poor kinetics of complex hydrides is the major reason for their irreversibility at moderate conditions. The kinetics of the hydrogenation/dehydrogenation reactions depend on the activation energy barrier $\left(E_{\mathrm{A}}, \mathrm{J}\right)$ and the reaction rate $\left(K_{\mathrm{r}}\right.$, which is a function of temperature) correlated by the Arrhenius rate equation as follows: ${ }^{[104]}$

$$
K_{\mathrm{r}}(T) \propto \mathrm{e}^{\wedge}\left(-E A /\left(k_{\mathrm{B}} T\right)\right)
$$

where $k_{\mathrm{B}}$ is the Boltzmann constant $\left(1.381 \times 10^{-23} \mathrm{~J} \cdot \mathrm{K}^{-1}\right)$. Hence, if the activation energy is high and/or the temperature is low, the reaction will proceed slowly. Therefore, it is essential to reduce the activation for both the dehydrogenation and rehydrogenation reactions to achieve fast hydrogen sorption rates.

Kinetic improvements upon nanoconfinement of complex hydrides have been reported in a large number of studies. 
General Chemistry

Nanoscaffolds have been claimed to act as catalysts ${ }^{[116]}$ influencing the interfacial energy and thus reducing the activation energy of decomposition. For example, $\mathrm{LiBH}_{4}$ melt infiltrated in mesoporous carbons showed a hydrogen desorption rate 50 times faster than pristine $\mathrm{LiBH}_{4}$ and a reduction of $E_{\mathrm{A}}$ of more than $40 \mathrm{~kJ} \cdot \mathrm{mol}^{-1}$ due to the increase in ionic mobility at the nanoscale. ${ }^{[14]}$ A similar observation was made for $\mathrm{Mg}\left(\mathrm{BH}_{4}\right)_{2}$ confined in carbon nanotubes. The activation energy was reduced from 451.6 to $130.2 \mathrm{~kJ} \cdot \mathrm{mol}^{-1}$ for the hydrogen desorption reaction. ${ }^{[117]}$ For nanoconfined $\mathrm{NaAlH}_{4}$ a reduction of activation energy from $116 \mathrm{~kJ} \cdot \mathrm{mol}^{-1}$ for bulk $\mathrm{NaAlH}_{4}$ to $58 \mathrm{~kJ} \cdot \mathrm{mol}^{-1}$ was also observed. ${ }^{[118]}$

From experimental evidences, it also appears that a decrease in pore size leads to an increase in hydrogen desorption rates for $\mathrm{LiBH}_{4}$ (e.g., 12.5 mass $\% \mathrm{H}_{2} \cdot \mathrm{h}^{-1}$ for $13 \mathrm{~nm}$ compared to 7.8 mass $\% \mathrm{H}_{2} \cdot \mathrm{h}^{-1}$ for $\left.25 \mathrm{~nm}\right)^{[114]}$ due to the reduction in diffusion distances. It is also expected that the scaffold acts as a cage that restricts particle growth and thus this improves the gas-solid interactions during hydrogen sorption. More recently, $\mathrm{NMR}^{[119-121]}$ and QENS ${ }^{[122,123]}$ analysis were utilized to understand the structure and dynamics of $\mathrm{LiBH}_{4}$ confined in porous nanostructures. Typical $\mathrm{J}$-coupling patterns were observed in both ${ }^{11} \mathrm{~B}$ and ${ }^{1} \mathrm{H}$ spectra for nanoconfined $\mathrm{LiBH}_{4}$, while the static measurement of ${ }^{11} \mathrm{~B}$ and ${ }^{7} \mathrm{Li}$ spectra showed lower solid-solid phase transition temperature compared to bulk $\mathrm{LiBH}_{4}{ }^{[120,121]}$ This indicated that the mobility of $\mathrm{BH}_{4}$ and $\mathrm{Li}^{+}$through the borohydride lattice was highly enhanced upon nanoconfinement. In particular, it was claimed that the translational and reorientational motions of $\left(\mathrm{BH}_{4}\right)^{-}$were significantly improved at the interface between $\left(\mathrm{BH}_{4}\right)^{-}$and the carbon pore. ${ }^{[122]}$ In addition, $\mathrm{Li}^{+}$conductivity was found to increase from $10^{-8}$ to $10^{-3}$ $\mathrm{S} \cdot \mathrm{cm}^{-1}$ at room temperature upon confinement in ordered mesoporous silica scaffolds. ${ }^{[121]}$

\section{Current approaches to nanoconfine borohydrides}

A good scaffold material needs to be light, highly porous, and have a low reactivity towards the hydride material. ${ }^{[05]}$ Most nanoconfinement syntheses have been so far carried out within inorganic hosts such as mesoporous silica and in particular porous carbons. ${ }^{[15,123,124]}$ Melt infiltration and solvent-based methods are the most popular methods for the nanoconfinement of borohydrides (Figure 8a). ${ }^{[111]}$ By melt infiltration, the hydrides is melted and thus impregnated within the host porous material under hydrogen pressure. ${ }^{[102]}$ By solution impregnation, a dissolved form of the hydride is infiltrated in the porosity of the porous scaffold, and the operation is repeated several times until the porosity is filled. However, it is often difficult to fill the porosity of the host materials entirely with these methods.

(a)
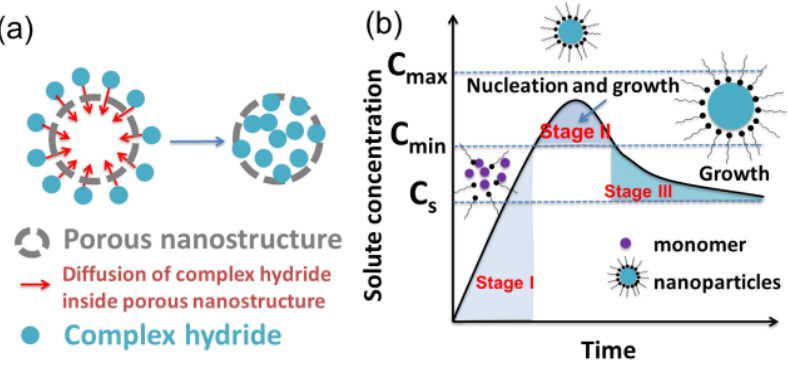

Figure 8 (a) Nanoconfinement of complex hydrides in nanoscaffolds via solvent impregnation or melt infiltration. (b) LaMer theory illustrating the processes of nucleation and subsequent growth of nanoparticles.

Ngene et al. ${ }^{[125]}$ reported the confinement of $\mathrm{LiBH}_{4}$ in
SBA-15 and hydrogen release started at $150{ }^{\circ} \mathrm{C}$. However, mesoporous silica materials were found to be inappropriate for nanoconfinement of complex hydrides due to the formation of stable silicates by-products. ${ }^{[26]} \mathrm{LiBH}_{4}$ melt infiltrated in porous carbon aerogels, with a pore size ranging from 13 to $25 \mathrm{~nm}$, showed a significant decrease in dehydrogenation temperature (by $75^{\circ} \mathrm{C}$ ), ${ }^{[114]}$ a fast dehydrogenation rate ${ }^{[111]}$ and a $40 \mathrm{~kJ} \cdot \mathrm{mol}^{-1}$ decrease in activation energy, compared to the bulk hydride. ${ }^{[02]}$ Reversibility for this confined borohydride was achieved at moderated conditions $\left(400{ }^{\circ} \mathrm{C}\right.$ with $10 \mathrm{MPa} \mathrm{H}_{2}$ pressure). ${ }^{[114]}$ Similarly, nanoconfinement of $\mathrm{LiBH}_{4}+\mathrm{MgH}_{2}$ led to lower desorption temperatures but with decreasing hydrogen cycling capacities. ${ }^{[111]}$ Even though nanoconfinement has positive influences on the hydrogen storage properties of borohydrides, there are still considerable issues associated with this approach. The scaffold material contributes to significant extra weight to the storage systems, which further reduces the gravimetric and volumetric density of hydrogen. For example, hydrides nanoconfined carbon materials have commonly hydrogen capacities lower than 1 mass\%.

Reversible hydrogen cycling is also a challenge for nanoconfined hydrides. Carbons are reactive towards hydrides because of the surface oxygen and hydroxyl groups. Thus, the hydrogen storage properties of nanoconfined materials might vary with time and become difficult to control and predict. Most importantly, the hydrogen storage capacity decreases continuously upon cycling owing to the oxidation and leaching of the hydride outside the mesoporosity of the carbon host. ${ }^{[127]}$ Characterisation of the nanoconfined material is an important step towards a better understanding of the thermodynamics and kinetics of hydrogen storage. However, this may be challenging because of the screening effect of the carbon surrounding the confined hydrides. ${ }^{[126]}$

The use of metal organic frameworks (MOFs) as host mesoporous structures has also been investigated. ${ }^{[128]}$ MOFs have been extensively studied for their ability to physisorb hydrogen due to their large surface area $\left(>2000 \mathrm{~m}^{2} \cdot \mathrm{g}^{-1}\right)$ as compared to other porous materials. ${ }^{[129]}$ Sun et al. ${ }^{[128]}$ claimed that the interaction between $\mathrm{LiBH}_{4}$ and $\mathrm{Cu}^{2+}$ led to a decrease of more than $300{ }^{\circ} \mathrm{C}$ in the dehydrogenation temperature of $\mathrm{LiBH}_{4}$ confined in a Cu-MOF. According to their finding, the confined $\mathrm{LiBH}_{4}$ undertook a redox reaction with $\mathrm{Cu}-\mathrm{O}$, which lowered the dehydrogenation temperature.

To increase the reversible hydrogen storage capacity achievable by nanoconfinement, Christian et al. proposed a core-shell approach, whereby the hydride core is encapsulated within a metallic shell permeable to hydrogen. This allows the confinement of the hydride and its decomposition products during melting and hydrogen release. A stable 5 mass $\%$ hydrogen content was cycled with the core shell $\mathrm{NaBH}_{4} @ \mathrm{Ni}$ structure at $350{ }^{\circ} \mathrm{C}$ under $4 \mathrm{MPa} \mathrm{H}_{2}$ pressure. ${ }^{[130]}$ The same approach was shown to apply towards the synthesis of $\mathrm{LiH} @ \mathrm{Ni}^{\left[{ }^{[131]}\right.}$ Hydrogen release from this nanostructure occurred from $70^{\circ} \mathrm{C}$, instead of the $700^{\circ} \mathrm{C}$ observed for bulk $\mathrm{LiH}$.

The advantage of this approach is that it has the potential to combine the benefits of both destabilisation and size effect, without the drawbacks of a dense porous scaffold. However, this requires the development of approaches for the synthesis of "free-standing" nanosized borohydride particles, since the synthesis of a core-shell complex hydrides starts with the production of a nano-core hydride, followed by the growth of the shell material on the surface of the core. Core-shell nanoparticles can thus have different structures (Figure 9), depending on the arrangement and interaction between the core and shell material.

The synthesis of the hydride core can be achieved by wet chemistry methods and by considering the theory of nucleation 


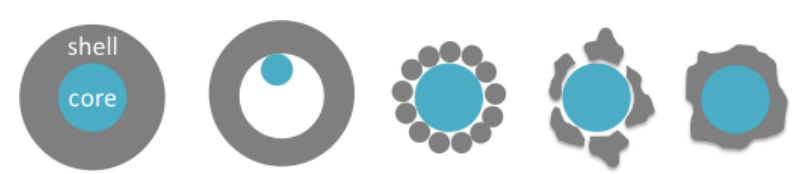

Figure 9 Illustration of various possible shapes of core-shell nanoparticles.

and growth and the LaMer mechanism to control the size of nanoparticles and their particle size dispersion (Figure 8b). ${ }^{[132]}$ In this case, various strategies including electrostatic repulsion or steric repulsion can be used to stabilize the hydride nanoparticles. ${ }^{[133]}$ However, it should be noted that hydride nanoparticles bring an additional level of complexity since the stabiliser needs to be inert to the hydride and only physically attached to the nanoparticle surface.

Precipitation is the most straightforward method for the synthesis of colloidal nanoparticles. ${ }^{[134]}$ Generally, methods including anti-solvent precipitation or solvent evaporation can be used (Figure 10). By using these techniques, Christian et al. have demonstrated the synthesis of $\mathrm{NaBH}_{4}$ nanoparticles with an average diameter of $5 \mathrm{~nm} .{ }^{[130]} \mathrm{Nano}$-sized $\mathrm{LiBH}_{4}$, with particle diameters varying from 20 to $50 \mathrm{~nm}$, were also successfully synthesised via solvent evaporation. The initial hydrogen release started at $32{ }^{\circ} \mathrm{C}$ and 1.7 mass $\%$ of hydrogen could be re-absorbed at $265{ }^{\circ} \mathrm{C}$ under $9 \mathrm{MPa} \mathrm{H}$ pressure. ${ }^{[135]}$ Similar $\mathrm{LiBH}_{4}$ nanoparticles were synthesised by Li et al. ${ }^{[136]}$ and these nanoparticles released hydrogen from $72{ }^{\circ} \mathrm{C}$. However, the formation mechanism of these nanoparticles upon solvent evaporation or precipitation is rather complex. Firstly, borohydrides have a high redox potential and can easily react with organic solvents and many surfactants. If non-reactive, the solvent may also strongly bind to the borohydrides, and thus complicate the drying process of the nanoparticles.

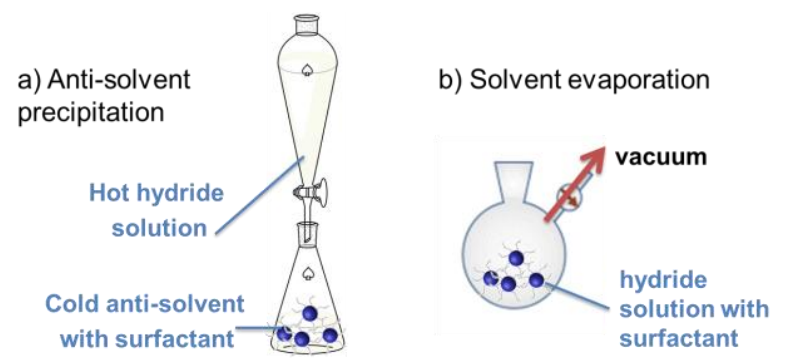

Figure 10 Wet chemistry approaches to synthesis nanoparticles of hydrides (a) anti-solvent precipitation and (b) solvent evaporations method.

The synthesis of nanoparticles of complex hydrides with capping agents alone is often not sufficient to enable adequate hydrogen properties and in particular hydrogen cycling. Hydride nanoparticles can still undergo crystalline phase changes, melting, and disproportionation. ${ }^{[33,45,137]}$ They also tend to retain the hydrogen storage properties of the bulk material due to the low thermal stability of the capping agents. ${ }^{[130]}$ Therefore, it is necessary to further stabilize these nanoparticles to minimize the effects of chemical/physical transformations that often occur upon cycling at elevated temperatures. As discussed above, the formation of a metallic-shell structure is a potential approach to enable this.

Synthesis of core-shell complex hydrides may seem straightforward; however, there are many factors that could affect the particle size shape and distribution. Firstly, the difference in redox potential between the shell metallic precursor and the hydride core can result in a different deposition rate of the metals. ${ }^{[138]}$ Secondly, the type of ligands stabilizing the surface of the core can also affect the reduction rate. ${ }^{[139]}$ Furthermore, the deposition of metal nuclei at the surface of the hydride core is thermodynamically and kinetically controlled. ${ }^{[140,141]}$ This means that different growth modes can be expected, depending on the interfacial energy between the growing shell and the core. The lattice mismatch between the core and shell materials can further influence the type of growth mode. ${ }^{[140]}$

\section{Future perspectives}

The main challenges of using complex hydrides as hydrogen storage materials are the high desorption temperature, slow kinetics and irreversibility of the sorption process. As discussed in the previous sections, these properties can be modified to some extent via stabilisation/destabilisation, catalyst addition and nanoconfinement approaches.

In this respect, nanoconfinement in conjunction with previous stabilization/destabilization attempts is believed to be the most promising approach. Conventional nanoconfinement approaches utilize nanoporous structures, ${ }^{[123]}$ i.e., carbon scaffolds, to encapsulate complex hydrides via melt infiltration or solution impregnation methods. The temperature for hydrogen release from the confined hydrides is largely decreased due to the higher ionic mobility at the nanoscale and the interaction with the wall of the scaffold. ${ }^{[19,120,122]}$ However, the effectiveness of nanoconfinement of borohydrides along these two main synthetic approaches is barely characterised. To further progress, it is thus important to compare these two techniques and explore any link between the synthesis conditions and the hydrogen properties of the nanoconfined borohydrides. The difficulty in filling the nanoporous structures as well as the reaction between the confined borohydride and the host material are additional drawbacks limiting the full determination of the thermodynamic properties of confined hydrides. ${ }^{[142]}$ Thus, the effect of different types of scaffolds on the hydrogen storage properties should also be investigated as to finally set grounds to determine accurate evolutions of enthalpy, entropy, activation energy as well as reaction paths upon the nanosizing of borohydrides.

Another way to nanoconfine borohydrides is the direct synthesis of their nanoparticles. However, the study of borohydride nanoparticles synthesis is only recent. ${ }^{[136,143]}$ The formation mechanism and interaction between the particle surface and stabilisers still remain unclear. It is necessary to investigate such interactions, so nanoparticles with defined morphologies, specific surface plane reactivity and nanostructures can be established and their properties linked to particular hydrogen storage behaviours. In this context of "free standing" nanosized borohydride particles synthesis, control of their melting behaviour is crucial. With the use of scaffolds, the leaching of the borohydrides outside the pores has been widely reported, ${ }^{[127]}$ which means that borohydrides still melt at the nanoscale. This can lead to a dispersion and segregation of the decomposition products and thus increased difficulties to achieve rehydrogenation. One potential approach to suppress the melting of borohydrides is through doping with transition metal halides, ${ }^{[144-146]}$ which have been shown to modify the melting temperature significantly and in some cases, modify the decomposition paths. ${ }^{[145,146]}$ Therefore, the nature of the melting behaviour of borohydrides and the role of halides in the modification of the melting should be studied.

To further improve the hydrogen storage capacity, it is essential to use a lightweight scaffold instead of the bulky carbon materials. The core-shell approach provides a potential path to solve the problem associated with the use of conventional scaffolds. This method allowed stable high reversible capacity 
General Chemistry

with nanosized $\mathrm{NaBH}_{4}$ for the first time. However, this requires a careful control of the synthetic process, since many factors can affect the particle size, shape and the growth mode of the shell. The growth of a uniform layer requires a careful consideration of the physical properties of the core and shell materials (i.e., lattice mismatch, electronegativity and bond-energy). It also requires precise control of the atomic diffusion at the surface of the core, which is governed by the reaction temperature and concentration of the monomer in the solution. Accordingly, a significant increase of our fundamental understating of such core-shell synthetic growth and behaviour during hydrogen cycling is required before one can control it towards the design of practical hydrogen storage materials.

\section{Conclusion}

Hydrogen is believed to be the ultimate energy carrier. The use of hydrogen and its storage with materials can enable much higher energy densities compared to conventional battery technologies. However, the practical application of hydrogen is still limited by the lack of high-density hydrogen storage materials with the capability to reversibly release and absorb hydrogen close to the ambient. In this respect, light metal borohydrides are of high interest but their high dehydrogenation temperature and their slow kinetics, leading to poor hydrogen reversibility are significant challenges towards application.

In recent years, some promising improvements on the storage properties of borohydride through stabilization/destabilization, catalysts and nanoconfinement have been achieved. Reactive hydride composites have shown great enhancement on the thermodynamic aspect of borohydrides, however, the hydrogen release kinetics remain still slow and often require the addition of catalysts. Meanwhile, the utilization of $\mathrm{H}^{\delta^{-}} / \mathrm{H}^{\delta-}$ interaction between borohydride and ammonia has shown some further improvements on the achievable hydrogen release temperature and kinetics, however, systems involving $\mathrm{H}^{\delta+} / \mathrm{H}^{\delta-}$ interaction often suffer from low hydrogen reversibility. In comparison, nanoconfinement seems to be a more promising method, owing to the ability to modify both the thermodynamic and kinetics of borohydrides at the same time. However, some drawbacks, such as low and degrading hydrogen capacities, limit the improvements observed so far.

The main challenge towards greater improvements is the lack of knowledge on the physical and chemical properties of borohydrides upon hydrogen release. It is essential to understand the exact decomposition paths and the role of the different reaction intermediates. This will require a combination of techniques, e.g., in-situ XRD, NMR and FTIR, due to the amorphous nature of many of the reaction intermediates. Even though the hydrogen adsorption/desorption processes in metal hydrides is well established, not all of these concepts can be simply transferred to a complex hydride systems. One limitation is the complexity of the decomposition of borohydrides, and in additional to the enthalpy evolution, significant entropic changes. The exact mechanism pertaining the formation and dissociation of $\mathrm{BH}_{4}$ as well as the associated diffusion mechanism, especially at a nanoscale, are still not sufficiently clear to guide pathways effectively towards better hydrogen reversibility. As a concluding remark, it is noteworthy that the potential of borohydrides is not limited to hydrogen storage application. Recent studies have shown great ionic conductivity in nanoconfined $\mathrm{LiBH}_{4}{ }^{[121,147]}$ even at room temperature, and this pave the way toward the use of borohydrides as potential solid electrolytes for rechargeable solid-state batteries. Borohydrides can also be potentially used as catalysts to facilitate the hydrogen uptake and release during chemical reactions, such as the hydrogenation of $\mathrm{CO}_{2}$, as demonstrated by many metal hydrides. $^{[148,149]}$

\section{References}

[1] International Energy Agency, World Energy Outlook, 2016.

[2] Stein, R. S.; Powers, J. The Energy Problem, World Scientific, Singapore, 2011.

[3] Ashina, S.; Fujino, J.; Masui, T.; Ehara, T.; Hibino, G. Energy Policy 2012, 41, 584.

[4] Lindley, D. Nature 2010, 463, 18.

[5] Bockris, J. M. Environ. This Month 1971, 51.

[6] Bockris, J. M.; Appleby, A. J. Environ. This Month 1972, 1, 29.

[7] Bockris, J. M. Int. J. Hydrogen Energy 2002, 27, 731.

[8] Crabtree, G. W.; Dresselhaus, M. S.; Buchanan, M. V. Phys. Today 2004, 57, 39.

[9] Erren, R. A. 1930, GB patent GB364180.

[10] Verhelst, S. Int. J. Hydrogen Energy 2014, 39, 1071.

[11] U.S. Department of Energy, 2011 Fuel Cell Technologies Market Report, Washington D.C., U.S.A., 2012.

[12] Christmann, K. Surf. Sci. Rep. 1988, 9, 1.

[13] Klebanoff, L. Hydrogen Storage Technology: Materials and Applications, CRC Press, U.S.A., 2012.

[14] He, T.; Pachfule, P.; Wu, H.; Xu, Q.; Chen, P. Nat. Rev. Mater. 2016, 1, 16059.

[15] Yu, X.; Tang, Z.; Sun, D.; Ouyang, L.; Zhu, M. Prog. Mater. Sci. 2017, 88, 1.

[16] Stan, G.; Cole, M. W. J. Low Temp. Phys. 1998, 110, 539.

[17] Williams, K. A.; Eklund, P. C. Chem. Phys. Lett. 2000, 320, 352.

[18] Züttel, A. Naturwissenschaften 2004, 91, 157.

[19] Graham, T. Proc. R. Soc. London 1869, 17, 212.

[20] Adams, B. D.; Chen, A. Mater. Today 2011, 14, 282.

[21] Van Vucht, J. H. N.; Kuijpers, F. A.; Bruning, H. C. A. M. Philips Res. Rep. 1970, 25, 133.

[22] Reilly, J. J.; Wiswall, R. H. Inorg. Chem. 1974, 13, 218.

[23] Hoffman, K. C.; Winsche, W. E.; Wiswall, R. H.; Reilly, J. J.; Sheehan, T. V.; Waide, C. H. SAE Trans. 1969, 78, 981.

[24] Buchner, H. Prog. Energy Combust. Sci. 1980, 6, 331.

[25] Gerard, N.; Ono, S. Hydrogen in Intermetallic Compounds, Springer-Verlag, Germany, 1992.

[26] Sakintuna, B.; Lamari-Darkrim, F.; Hirscher, M. Int. J. Hydrogen Energy 2007, 32, 1121.

[27] Schlapbach, L.; Züttel, A. Nature 2001, 414, 353.

[28] Zhou, L. Renew. Sust. Energ. Rev. 2005, 9, 395.

[29] Sun, Y.; Shen, C.; Lai, Q.; Liu, W.; Wang, D.-W.; Aguey-Zinsou, K.-F. Energy Storage Mater. 2017, 10, 168.

[30] Züttel, A.; Wenger, P.; Rentsch, S.; Sudan, P. H.; Mauron, P.; Emmenegger, C. J. Power Sources 2003, 118, 1.

[31] Graetz, J. Chem. Soc. Rev. 2009, 38, 73.

[32] Mohtadi, R.; Orimo, S.-I. Nat. Rev. Mater. 2017, 2, 16091.

[33] Orimo, S.; Nakamori, Y.; Eliseo, J. R.; Züttel, A.; Jensen, C. M. Chem. Rev. 2007, 107, 4111.

[34] Ohba, N.; Miwa, K.; Aoki, M.; Noritake, T.; Towata, S.; Nakamori, Y.; Orimo, S.; Züttel, A. Phys. Rev. B 2006, 74, 075110.

[35] Züttel, A.; Borgschulte, A.; Orimo, S. Scripta Mater. 2007, 56, 823.

[36] Pitt, M. P.; Paskevicius, M.; Brown, D. H.; Sheppard, D. A.; Buckley, C. E. J. Am. Chem. Soc. 2013, 135, 6930.

[37] Mauron, P.; Buchter, F.; Friedrichs, O.; Remhof, A.; Bielmann, M.; Zwicky, C. N.; Züttel, A. J. Phys. Chem. B 2008, 112, 906.

[38] Smith, M. B.; Bass Jr, G. E. J. Chem. Eng. Data 1963, 8, 342.

[39] Miwa, K.; Ohba, N.; Towata, S.; Nakamori, Y.; Orimo, S. Phys. Rev. B 2004, 69, 245120.

[40] Nakamori, Y.; Miwa, K.; Ninomiya, A.; Li, H.; Ohba, N.; Towata, S.; Züttel, A.; Orimo, S. Phys. Rev. B 2006, 74, 045126.

[41] Pendolino, F.; Mauron, P.; Borgschulte, A.; Züttel, A. J. Phys. Chem. C 2009, 113, 17231.

[42] Yang, J.; Hirano, S. Adv. Mater. 2009, 21, 3023.

[43] Orimo, S.; Nakamori, Y.; Kitahara, G.; Miwa, K.; Ohba, N.; Towata, 
S.; Züttel, A. J. Alloys Compd. 2005, 404-406, 427.

[44] Urgnani, J.; Torres, F.; Palumbo, M.; Baricco, M. Int. J. Hydrogen Energy 2008, 33, 3111.

[45] Lai, Q.; Paskevicius, M.; Sheppard, D. A.; Buckley, C. E.; Thornton, A. W.; Hill, M. R.; Gu, Q.; Mao, J.; Huang, Z.; Liu, H. K.; Guo, Z.; Banerjee, A.; Chakraborty, S.; Ahuja, R.; Aguey-Zinsou, K.-F. ChemSusChem 2015, 8, 2789.

[46] Hanada, N.; Chłopek, K.; Frommen, C.; Lohstroh, W.; Fichtner, M. J. Mater. Chem. 2008, 18, 2611

[47] Rönnebro, E.; Majzoub, E. H. J. Phys. Chem. B 2007, 111, 12045.

[48] Miwa, K.; Aoki, M.; Noritake, T.; Ohba, N.; Nakamori, Y.; Towata, S.; Züttel, A.; Orimo, S. Phys. Rev. B 2006, 74, 155122.

[49] Matsunaga, T.; Buchter, F.; Mauron, P.; Bielman, M.; Nakamori, Y.; Orimo, S.; Ohba, N.; Miwa, K.; Towata, S.; Züttel, A. J. Alloys Compd. 2008, 459, 583.

[50] Li, H.; Kikuchi, K.; Nakamori, Y.; Ohba, N.; Miwa, K.; Towata, S.; Orimo, S. Acta Mater. 2008, 56, 1342.

[51] Severa, G.; Ronnebro, E.; Jensen, C. M. Chem. Commun. 2010, 46, 421.

[52] Pistidda, C.; Garroni, S.; Dolci, F.; Bardají, E. G.; Khandelwal, A.; Nolis, P.; Dornheim, M.; Gosalawit, R.; Jensen, T.; Cerenius, Y.; Suriñach, S.; Baró, M. D.; Lohstroh, W.; Fichtner, M. J. Alloys Compd. 2010, 508, 212.

[53] Pitt, M. P.; Webb, C. J.; Paskevicius, M.; Sheptyakov, D.; Buckley, C. E.; Gray, E. M. J. Phys. Chem. C 2011, 115, 22669.

[54] Mao, J.; Guo, Z.; Poh, C. K.; Ranjbar, A.; Guo, Y.; Yu, X.; Liu, H. J. Alloys Compd. 2010, 500, 200.

[55] Rönnebro, E. Curr. Opin. Solid State Mater. Sci. 2011, 15, 44.

[56] Riktor, M. D.; Sørby, M. H.; Muller, J.; Bardají, E. G.; Fichtner, M.; Hauback, B. C. J. Alloys Compd. 2015, 632, 800.

[57] Kim, J.-H.; Jin, S.-A.; Shim, J.-H.; Cho, Y. W. Scripta Mater. 2008, $58,481$.

[58] Wang, L.-L.; Graham, D. D.; Robertson, I. M.; Johnson, D. D. J. Phys. Chem. C 2009, 113, 20088.

[59] Bogdanović, B.; Schwickardi, M. J. Alloys Compd. 1997, 253, 1.

[60] Yang, J.; Sudik, A.; Wolverton, C. J. Phys. Chem. C, 2007, 111, 19134.

[61] Pinkerton, F.; Meyer, M. J. Alloys Compd. 2008, 464, L1.

[62] Jin, S.-A.; Lee, Y.-S.; Shim, J.-H.; Cho, Y. W. J. Phys. Chem. C 2008, 112, 9520.

[63] Vajo, J. J.; Li, W.; Liu, P. Chem. Commun. 2010, 46, 6687.

[64] Zhou, Y.; Liu, Y.; Zhang, Y.; Gao, M.; Pan, H. Dalton Trans. 2012, 41, 10980.

[65] Liu, D.; Liu, Q.; Si, T.; Zhang, Q.; Fang, F.; Sun, D.; Ouyang, L.; Zhu, M. Chem. Commun. 2011, 47, 5741.

[66] Zhou, Y.; Liu, Y.; Wu, W.; Zhang, Y.; Gao, M.; Pan, H. J. Phys. Chem. C 2011, 116, 1588.

[67] Li, C.; Peng, P.; Zhou, D. W.; Wan, L. Int. J. Hydrogen Energy 2011, 36, 14512.

[68] Vajo, J. J.; Skeith, S. L.; Mertens, F. J. Phys. Chem. B 2005, 109, 3719.

[69] Mao, J. F.; Wu, Z.; Chen, T. J.; Weng, B. C.; Xu, N. X.; Huang, T. S.; Guo, Z. P.; Liu, H. K.; Grant, D. M.; Walker, G. S.; Yu, X. B. J. Phys. Chem. C 2007, 111, 12495.

[70] Yu, X. B.; Grant, D. M.; Walker, G. S. J. Phys. Chem. C 2009, 113, 17945.

[71] Price, T. E. C.; Grant, D. M.; Legrand, V.; Walker, G. S. Int. J. Hydrogen Energy 2010, 35, 4154.

[72] Yu, X.; Grant, D.; Walker, G. Chem. Commun. 2006, 3906.

[73] Nakagawa, T.; Ichikawa, T.; Hanada, N.; Kojima, Y.; Fujii, H. J. Alloys Compd. 2007, 446, 306.

[74] Pinkerton, F. E.; Meyer, M. S.; Meisner, G. P.; Balogh, M. P.; Vajo, J. J. J. Phys. Chem. C 2007, 111, 12881.

[75] Bosenberg, U.; Ravnsbaek, D. B.; Hagemann, H.; D'Anna, V.; Minella, C. B.; Pistidda, C.; van Beek, W.; Jensen, T. R.; Bormann, R.; Dornheim, M. J. Phys. Chem. C 2010, 114, 15212
[76] Kang, X.; Wang, P.; Ma, L.; Cheng, H. Appl. Phys. A 2007, 89 963.

[77] Pinkerton, F. E.; Meisner, G. P.; Meyer, M. S.; Balogh, M. P.; Kundrat, M. D. J. Phys. Chem. B 2005, 109, 6.

[78] Meisner, G. P.; Scullin, M. L.; Balogh, M. P.; Pinkerton, F. E.; Meyer, M. S. J. Phys. Chem. B 2006, 110, 4186.

[79] Lewis, G. J.; Sachtler, J. W. A.; Low, J. J.; Lesch, D. A.; Faheem, S. A.; Dosek, P. M.; Knight, L. M.; Halloran, L.; Jensen, C. M.; Yang, J. J. Alloys Compd. 2007, 446, 355.

[80] Sudik, A.; Yang, J.; Siegel, D. J.; Wolverton, C.; Carter III, R. O.; Drews, A. J. Phys. Chem. C 2009, 113, 2004.

[81] Li, H.; Orimo, S.; Nakamori, Y.; Miwa, K.; Ohba, N.; Towata, S.; Züttel, A. J. Alloys Compd. 2007, 446, 315.

[82] Hagemann, H., M. Longhini, J. W. Kaminski, T. A. Wesolowski, R. Cerny, N. Penin, M. H. Sørby, B. C. Hauback, G. Severa and C. M. Jensen, J. Phys. Chem. A 2008, 112, 7551.

[83] Ravnsbæk, D.; Filinchuk, Y.; Cerenius, Y.; Jakobsen, H. J.; Besenbacher, F.; Skibsted, J.; Jensen, T. R. Angew. Chem. 2009, $121,6787$.

[84] Kim, C.; Hwang, S.-J.; Bowman Jr, R. C.; Reiter, J. W.; Zan, J. A.; Kulleck, J. G.; Kabbour, H.; Majzoub, E.; Ozolins, V. J. Phys. Chem. C 2009, 113, 9956.

[85] Cerny, R.; Severa, G.; Ravnsbæk, D. B.; Filinchuk, Y.; D’Anna, V.; Hagemann, H.; Haase, D. R.; Jensen, C. M.; Jensen, T. R. J. Phys. Chem. C 2009, 114, 1357.

[86] Cerny, R.; Ravnsbæk, D. B.; Severa, G.; Filinchuk, Y.; D’Anna, V.; Hagemann, H.; Haase, D. R.; Skibsted, J.; Jensen, C. M.; Jensen, T. R. J. Phys. Chem. C 2010, 114, 19540.

[87] Au, M.; Meziani, M. J.; Sun, Y.; Pinkerton, F. E. J. Phys. Chem. C 2011, 115, 20765

[88] Xia, G.; Gu, Q.; Guo, Y.; Yu, X. J. Mater. Chem. 2012, 22, 7300.

[89] Lippard, S. J. Progress in Inorganic Chemistry, Volume 11, John Wiley \& Sons, Inc., New York, 1970.

[90] Guo, Y.; Wu, H.; Zhou, W.; Yu, X. J. Am. Chem. Soc. 2011, 133, 4690.

[91] Guo, Y.; Yu, X.; Sun, W.; Sun, D.; Yang, W. Angew. Chem. 2011, 123, 1119.

[92] Gu, Q.; Gao, L.; Guo, Y.; Tan, Y.; Tang, Z.; Wallwork, K. S.; Zhang, F.; Yu, X. Energy Environ. Sci. 2012, 5, 7590.

[93] Tang, Z.; Tan, Y.; Chen, X.; Ouyang, L.; Zhu, M.; Sun, D.; Yu, X. Angew. Chem. Int. Ed. 2013, 52, 12659.

[94] Yuan, F.; Gu, Q.; Chen, X.; Tan, Y.; Guo, Y.; Yu, X. Chem. Mater 2012, 24, 3370.

[95] Guo, Y.; Yu, X.; Gao, L.; Xia, G.; Guo, Z.; Liu, H.-K. Energy Environ. Sci. 2010, 3, 464.

[96] Zhang, B. J.; Liu, B. H. Int. J. Hydrogen Energy 2010, 35, 7288.

[97] Grochala, W.; Edwards, P. P. Chem. Rev. 2004, 104, 1283.

[98] Xia, G.; Guo, Y.; Wu, Z.; Yu, X. J. Alloys Compd. 2009, 479, 545.

[99] Ngene, P.; van Zwienen, M. R.; de Jongh, P. E. Chem. Commun. 2010, 46, 8201.

[100] Ngene, P.; Verkuijlen, M. H.; Zheng, Q.; Kragten, J.; van Bentum, P. J. M.; Bitter, J. H.; de Jongh, P. E. Faraday Discuss. 2011, 151, 47.

[101] Au, M.; Jurgensen, A.; Zeigler, K. J. Phys. Chem. B 2006, 110, 26482.

[102] Rude, L. H.; Nielsen, T. K.; Ravnsbæk, D. B.; Bösenberg, U.; Ley, M. B.; Richter, B.; Arnbjerg, L. M.; Dornheim, M.; Filinchuk, Y.; Besenbacher, F. Phys. Status Solidi A 2011, 208, 1754.

[103] Fichtner, M. Phys. Chem. Chem. Phys. 2011, 13, 21186.

[104] Bérubé, V.; Radtke, G.; Dresselhaus, M.; Chen, G. Int. J. Energ. Res. 2007, 31, 637.

[105] de Jongh, P. E.; Adelhelm, P. ChemSusChem 2010, 3, 1332.

[106] Wagemans, R. W.; van Lenthe, J. H.; de Jongh, P. E.; Van Dillen, A. J.; de Jong, K. P. J. Am. Chem. Soc. 2005, 127, 16675.

[107] Vajeeston, P.; Ravindran, P.; Fjellvåg, H. Nanotechnology 2008, $19,275704$. 
General Chemistry

[108] Vajeeston, P.; Ravindran, P.; Fjellvåg, H. Nanotechnology 2009, 20, 275704.

[109] Kim, K. C.; Dai, B.; Johnson, J. K.; Sholl, D. S. Nanotechnology 2009, 20, 204001.

[110] Colognesi, D.; Giannasi, A.; Ulivi, L.; Zoppi, M.; Ramirez-Cuesta, A. J.; Roth, A.; Fichtner, M. J. Phys. Chem. A 2011, 115, 7503.

[111] Vajo, J. J. Curr. Opin. Solid State Mater. Sci. 2011, 15, 52.

[112] Verkuijlen, M. H. W.; Gao, J.; Adelhelm, P.; van Bentum, P. J. M.; de Jongh, P. E.; Kentgens, A. P. M. J. Phys. Chem. C 2010, 114, 4683.

[113] Ozolins, V.; Majzoub, E. H.; Udovic, T. J. J. Alloys Compd. 2004, $375,1$.

[114] Gross, A. F.; Vajo, J. J.; Van Atta, S. L.; Olson, G. L. J. Phys. Chem. C 2008, 112, 5651.

[115] Ozolins, V.; Majzoub, E. H.; Wolverton, C. J. Am. Chem. Soc. 2008, 131, 230.

[116] Yu, X.; Wu, Z.; Chen, Q.; Li, Z.; Weng, B.; Huang, T. Appl. Phys. Lett. 2007, 90, 034106.

[117] Jiang, Z.; Yuan, J.; Han, H.; Wu, Y. J. Alloys Compd. 2018, 743, 11.

[118] Baldé, C. P.; Hereijgers, B. P. C.; Bitter, J. H.; Jong, K. P. D. J. Am. Chem. Soc. 2008, 130, 6761.

[119] Shane, D. T.; Corey, R. L.; Mclntosh, C.; Rayhel, L. H.; Bowman Jr, R. C.; Vajo, J. J.; Gross, A. F.; Conradi, M. S. J. Phys. Chem. C 2010, 114, 4008.

[120] Verkuijlen, M. H. W.; Ngene, P.; de Kort, D. W.; Barre, C.; Nale, A.; van Eck, E. R. H.; van Bentum, P. J. M.; de Jongh, P. E.; Kentgens, A. P. M. J. Phys. Chem. C 2012, 116, 22169.

[121] Blanchard, D.; Nale, A.; Sveinbjörnsson, D.; Eggenhuisen, T. M.; Verkuijlen, M. H. W.; Vegge, T.; Kentgens, A. P. M.; de Jongh, P. E. Adv. Funct. Mater. 2015, 25, 184.

[122] Liu, X.; Majzoub, E. H.; Stavila, V.; Bhakta, R. K.; Allendorf, M. D.; Shane, D. T.; Conradi, M. S.; Verdal, N.; Udovic, T. J.; Hwang, S.-J. J. Mater. Chem. A 2013, 1, 9935.

[123] Remhof, A.; Mauron, P.; Züttel, A.; Embs, J. P.; Łodziana, Z.; Ramirez-Cuesta, A. J.; Ngene, P.; de Jongh, P. J. Phys. Chem. C 2013, 117, 3789.

[124] Niemann, M. U.; Srinivasan, S. S.; Phani, A. R.; Kumar, A.; Goswami, D. Y.; Stefanakos, E. K. J. Nanomater. 2008, 2008.

[125] Ngene, P.; Adelhelm, P.; Beale, A. M.; de Jong, K. P.; de Jongh, P. E. J. Phys. Chem. C 2010, 114, 6163.

[126] Nielsen, T. K.; Besenbacher, F.; Jensen, T. R. Nanoscale 2011, 3, 2086.

[127] Lai, Q.; Christian, M.; Aguey-Zinsou, K.-F. Int. J. Hydrogen Energy 2014, 39, 9339.

[128] Sun, W.; Li, S.; Mao, J.; Guo, Z.; Liu, H.; Dou, S.; Yu, X. Dalton Trans. 2011, 40, 5673.

[129] Panella, B.; Hirscher, M.; Pütter, H.; Müller, U. Adv. Funct. Mater. 2006, 16, 520 .

[130] Christian, M.; Aguey-Zinsou, K.-F. ACS Nano 2012, 6, 7739.

[131] Wang, L.; Quadir, M.; Aguey-Zinsou, K.-F. Int. J. Hydrogen Energy 2016, 41, 6376.

[132] LaMer, V. K.; Dinegar, R. H. J. Am. Chem. Soc. 1950, 72, 4847.

[133] Christian, M. Ph.D. Dissertation, University of New South Wales, 2013.

[134] Sinha, B.; Müller, R. H.; Möschwitzer, J. P. Int. J. Pharm. 2013, 453, 126.

[135] Wan, X.; Shaw, L. L. Acta Mater. 2011, 59, 4606.

[136] Li, Y.; Zhang, Q.; Fang, F.; Song, Y.; Sun, D.; Ouyang, L.; Zhu, M. RSC Adv. 2014, 4, 983.

[137] Fichtner, M. Nanotechnology 2009, 20.

[138] Sankar, M.; Dimitratos, N.; Miedziak, P. J.; Wells, P. P.; Kiely, C. J.; Hutchings, G. J. Chem. Soc. Rev. 2012, 41, 8099

[139] Gu, J.; Zhang, Y.; Tao, F. F. Chem. Soc. Rev. 2012, 41, 8050.

[140] Zhang, Z.; Lagally, M. G. Science 1997, 276, 377.

[141] Lai, Q.; Wang, T.; Sun, Y.; Aguey-Zinsou, K. F. Adv. Mater.
Technol. 2018, 1700298.

[142] Javadian, P.; Sheppard, D. A.; Buckley, C. E.; Jensen, T. R. Nano Energy 2015, 11, 96.

[143] Christian, M.; Aguey-Zinsou, K.-F. Chem. Commun. 2013, 49, 6794.

[144] Au, M.; Jurgensen, A. R.; Spencer, W. A.; Anton, D. L.; Pinkerton, F. E.; Hwang, S.; Kim, C.; Bowman Jr, R. C. J. Phys. Chem. C 2008, 112, 18661.

[145] Lee, J. Y.; Lee, Y.-S.; Suh, J.-Y.; Shim, J.-H.; Cho, Y. W. J. Alloys Compd. 2010, 506, 721.

[146] Lai, Q.; Milanese, C.; Aguey-Zinsou, K.-F. ACS Appl. Energy Mater. 2018, 1, 421

[147] Ikeshoji, T.; Tsuchida, E.; Morishita, T.; Ikeda, K.; Matsuo, M.; Kawazoe, Y.; Orimo, S. Phys. Rev. B 2011, 83, 144301.

[148] Kato, S.; Borgschulte, A.; Ferri, D.; Bielmann, M.; Crivello, J.-C.; Wiedenmann, D.; Parlinska-Wojtan, M.; Rossbach, P.; Lu, Y.; Remhof, A. Phys. Chem. Chem. Phys. 2012, 14, 5518.

[149] Kato, S.; Matam, S. K.; Kerger, P.; Bernard, L.; Battaglia, C.; Vogel, D.; Rohwerder, M.; Züttel, A. Angew. Chem. Int. Ed. 2016, 55, 6028.

[150] Züttel, A.; Rentsch, S.; Fischer, P.; Wenger, P.; Sudan, P.; Mauron, P.; Emmenegger, C. J. Alloys Compd. 2003, 356, 515.

[151] Laversenne, L; Bonnetot, B. Annales de Chimie-Science des Materiaux 2005, 30, 495.

[152] Soloveichik, G. L. Mater. Matters 2007, 2, 11.

[153] Davis, W. D.; Mason, L.; Stegeman, G. J. Am. Chem. Soc. 1949, $71,2775$.

[154] Nickels, E. A.; Jones, M. O.; David, W. I.; Johnson, S. R.; Lowton, R. L.; Sommariva, M.; Edwards, P. P. Angew. Chem. Int. Ed. 2008 , 47, 2817.

[155] Fang, Z.; Kang, X.; Luo, J.; Wang, P.; Li, H.; Orimo, S. J. Phys. Chem. C 2010, 114, 22736.

[156] Lee, J. Y.; Ravnsbæk, D.; Lee, Y.-S.; Kim, Y.; Cerenius, Y.; Shim, J.-H.; Jensen, T. R.; Hur, N. H.; Cho, Y. W. J. Phys. Chem. C 2009, 113, 15080.

[157] Chong, M.; Callini, E.; Borgschulte, A.; Züttel, A.; Jensen, C. M. RSC Adv. 2014, 4, 63933.

[158] Jaroń, T.; Orłowski, P. A.; Wegner, W.; Fijałkowski, K. J.; Leszczyński, P. J.; Grochala, W. Angew. Chem. Int. Ed. 2015, 54, 1236.

[159] Seballos, L.; Zhang, J. Z.; Rönnebro, E.; Herberg, J. L.; Majzoub, E. J. Alloys Compd. 2009, 476, 446.

[160] Severa, G.; Hagemann, H.; Longhini, M. S.; Kaminski, J. W.; Wesolowski, T. A.; Jensen, C. M. J. Phys. Chem. C 2010, 114, 15516.

[161] Schouwink, P.; D’Anna, V.; Ley, M. B.; Lawson Daku, L. V. M.; Richter, B.; Jensen, T. R.; Hagemann, H.; Černyї, R. J. Phys. Chem. C 2012, 116, 10829.

[162] Dovgaliuk, I.; Ban, V.; Sadikin, Y.; ČernyÏ, R.; Aranda, L.; Casati, N.; Devillers, M.; Filinchuk, Y. J. Phys. Chem. C 2013, 118, 145.

[163] Knight, D. A.; Zidan, R.; Lascola, R.; Mohtadi, R.; Ling, C.; Sivasubramanian, P.; Kaduk, J. A.; Hwang, S.-J.; Samanta, D.; Jena, P. J. Phys. Chem. C 2013, 117, 19905.

[164] Roedern, E.; Jensen, T. R. J. Phys. Chem. C 2014, 118, 23567.

[165] Martelli, P.; Caputo, R.; Remhof, A.; Mauron, P.; Borgschulte, A.; Züttel, A. J. Phys. Chem. C 2010, 114, 7173.

[166] Stephens, R. D.; Gross, A. F.; Van Atta, S. L.; Vajo, J. J.; Pinkerton, F. E. Nanotechnology 2009, 20, 204018.

[167] Yan, Y.; Remhof, A.; Hwang, S.-J.; Li, H.; Mauron, P.; Orimo, S.; Züttel, A. Phys. Chem. Chem. Phys. 2012, 14, 6514.

Received July 5, 2018 Accepted August 1, 2018 